\title{
Testing of candidate non-lethal sampling methods for detection of Renibacterium salmoninarum in juvenile Chinook salmon Oncorhynchus tshawytscha
}

\author{
Diane G. Elliott*, Constance L. McKibben, Carla M. Conway, Maureen K. Purcell, \\ Dorothy M. Chase, LynnMarie J. Applegate
}

US Geological Survey, Western Fisheries Research Center, 6505 Northeast 65th Street, Seattle, Washington 98115, USA

\begin{abstract}
Non-lethal pathogen testing can be a useful tool for fish disease research and management. Our research objectives were to determine if (1) fin clips, gill snips, surface mucus scrapings, blood draws, or kidney biopsies could be obtained non-lethally from 3 to $15 \mathrm{~g}$ Chinook salmon Oncorhynchus tshawytscha, (2) non-lethal samples could accurately discriminate between fish exposed to the bacterial kidney disease agent Renibacterium salmoninarum and non-exposed fish, and (3) non-lethal samples could serve as proxies for lethal kidney samples to assess infection intensity. Blood draws and kidney biopsies caused $\geq 5 \%$ post-sampling mortality (Objective 1) and may be appropriate only for larger fish, but the other sample types were non-lethal. Sampling was performed over 21 wk following $R$. salmoninarum immersion challenge of fish from 2 stocks (Objectives 2 and 3), and nested PCR (nPCR) and real-time quantitative PCR (qPCR) results from candidate non-lethal samples were compared with kidney tissue analysis by nPCR, qPCR, bacteriological culture, enzyme-linked immunosorbent assay (ELISA), fluorescent antibody test (FAT) and histopathology/immunohistochemistry. R. salmoninarum was detected by PCR in $>50 \%$ of fin, gill, and mucus samples from challenged fish. Mucus qPCR was the only non-lethal assay exhibiting both diagnostic sensitivity and specificity estimates $>90 \%$ for distinguishing between $R$. salmoninarum-exposed and non-exposed fish and was the best candidate for use as an alternative to lethal kidney sample testing. Mucus qPCR $R$. salmoninarum quantity estimates reflected changes in kidney bacterial load estimates, as evidenced by significant positive correlations with kidney $R$. salmoninarum infection intensity scores at all sample times and in both fish stocks, and were not significantly impacted by environmental $R$. salmoninarum concentrations.
\end{abstract}

KEY WORDS: Bacterial kidney disease $\cdot$ Non-lethal sampling $\cdot$ Renibacterium salmoninarum • Salmonid $\cdot$ Polymerase chain reaction $\cdot$ PCR

\section{INTRODUCTION}

Renibacterium salmoninarum, the causative agent of bacterial kidney disease (BKD), is widespread in most parts of the world where captive or natural populations of salmonid fishes are present, and the bacterium and disease have been extensively reviewed (Fryer \& Sanders 1981, Evenden et al. 1993, Fryer \& Lannan 1993, Pascho et al. 2002). Typically a chronic disease, BKD can cause significant morbidity and mortality in salmonids at most life stages in both fresh water and seawater. $R$. salmoninarum is a slowly replicating gram-positive diplobacillus that has fastidious nutritional requirements and has not been demonstrated to persist outside the fish host for prolonged periods. Dual modes of transmission, horizontal and vertical, help to sustain $R$. salmoninarum in fish populations. The bacterium can be transmitted 
to naïve fish by cohabitation with infected fish in fresh water (Mitchum \& Sherman 1981, Bell et al. 1984, Alcorn et al. 2005) and seawater (Murray et al. 1992, Evelyn 1993), and entry sites are believed to include the gastrointestinal tract via ingestion of infected fish carcasses (Wood \& Wallis 1955) or feces (Balfry et al. 1996), and surface tissues through sites of injury (Wolf \& Dunbar 1959, Hendricks \& Leek 1975, Hayakawa et al. 1989, Elliott \& Pascho 2001). Transmission of $R$. salmoninarum from parent to progeny occurs in association with the egg, with at least some of the bacteria carried intra-ovum (Evelyn et al. 1984, 1986, Bruno \& Munro 1986). Characteristically, BKD manifests as a slowly progressing systemic granulomatous disease, but localized $R$. salmoninarum infections, with lesions confined to post-orbital or ocular tissues, brain or skin, have also been described (Hendricks \& Leek 1975, Hoffmann et al. 1984, Ferguson 1989, Speare 1997). The bacterium has been reported to exist in some fish populations for extended periods as subclinical infections (Meyers et al. 1993, Lovely et al. 1994, Starliper \& Teska 1995, Jónsdóttir et al. 1998), but overt disease can develop in such populations under the influence of exogenous stressors (Holey et al. 1998, Munson et al. 2010).

A variety of diagnostic tests have been developed to detect $R$. salmoninarum in tissues of infected fish (see Pascho et al. 2002 for a review). Bacteriological culture has been reported to be sensitive enough to support the growth of single $R$. salmoninarum cells (Evelyn 1977), but the extremely slow growth of $R$. salmoninarum colonies (Benediktsdóttir et al. 1991) and potential for overgrowth of cultures by contaminating organisms (Sakai et al. 1987, Gudmundsdóttir et al. 1991, Olsen et al. 1992) has prompted the development of a number of immunological and molecular methods for more rapid detection and specific identification of $R$. salmoninarum. The most commonly used non-culture $R$. salmoninarum assays include the fluorescent antibody test (FAT), enzyme-linked immunosorbent assay (ELISA), and non-quantitative and quantitative procedures for the polymerase chain reaction (PCR) (Pascho et al. 2002, Elliott et al. 2013).

Although $R$. salmoninarum can be detected nonlethally in ovarian fluid samples from spawning female salmonids (OIE 2003, AFS-FHS 2014), detection of infections in non-spawning fish usually involves lethal sampling of tissues. Development of effective non-lethal sampling methods for accurate $R$. salmoninarum detection in fish would reduce the need to sacrifice large numbers of individuals in threatened and endangered salmonid populations for pathogen inspections and surveys, and repeated non-lethal sampling could improve $R$. salmoninarum surveillance and management programs in fish culture facilities (Cipriano et al. 1992, Badil et al. 2011). In addition, application of non-lethal sampling methods for detection of $R$. salmoninarum in fish tissues could enhance studies of the pathogenesis and ecology of $R$. salmoninarum. For example, non-lethal detection of $R$. salmoninarum in juvenile fish would allow monitoring of their performance and survival after testing through the use of tags or other marks for identification of individual fish or specific groups of fish (Badil et al. 2011), and could generate data useful for developing predictive models of the dynamics of $R$. salmoninarum infections in salmonid populations.

Several types of samples have been successfully employed for non-lethal detection of bacterial, viral, and parasitic pathogens in fish. Among the sample types that have been used for non-lethal pathogen detection in salmonids are fin clips (Skirpstunas et al. 2006, Bowers et al. 2008, Dhar et al. 2008, Cornwell et al. 2013), gill tissue snips (Badil et al. 2011), blood samples (Altinok et al. 2001, Giray et al. 2005, López-Vázquez et al. 2006), kidney biopsies (Noga et al. 1988, White et al. 1996), and mucus samples (LaPatra et al. 1989, Cipriano et al. 1992, DouglasHelders et al. 2001). Few of these candidate nonlethal samples have been tested for $R$. salmoninarum detection, however. Kidney tissue is a standard lethal sample for $R$. salmoninarum detection (OIE 2003, Fisheries and Oceans Canada 1984, revised 2004, AFS-FHS 2014), and has been employed for non-lethal detection of $R$. salmoninarum in adult steelhead trout Oncorhynchus mykiss by FAT and histopathology/immunohistochemistry (White et al. 1996). Sensitive detection of this pathogen in blood samples has been reported for ELISA (Pascho et al. 1987) and PCR (Rhodes et al. 1998, Bruno et al. 2007). Preliminary research has also demonstrated that $R$. salmoninarum can be detected by PCR in gill samples from migrating juvenile salmonids (Badil et al. 2011).

Testing by PCR has become increasingly popular for fish pathogen detection, and advantages for use with non-lethal samples include high sensitivity and specificity, as well as the ability to rapidly test samples of low weights or volumes (Pascho et al. 2002, Purcell et al. 2011). Increased sensitivity in comparison to culture has been reported for non-lethal detection of the gram-negative fish pathogens Yersinia ruckeri in blood (Altinok et al. 2001) and Tenaciba- 
culum maritimum in mucus (Avendaño-Herrera et al. 2004) by conventional PCR. Real-time PCR offers additional benefits of high throughput and quantitative abilities (Purcell et al. 2011). Although PCRbased non-lethal sampling methods have shown promise for monitoring $R$. salmoninarum infections in preliminary studies, the sensitivity, specificity and biological significance of $R$. salmoninarum detection in non-lethal samples is largely unknown. The capability to detect a higher proportion of fish that give a positive test in a population does not necessarily represent an improvement in diagnostic ability, unless the data about those fish can be clearly demonstrated to provide useful management information or improved epidemiological understanding.

The purpose of this study was to conduct laboratory testing for evaluation of potential non-lethal sampling methods and PCR assays for detection of $R$. salmoninarum in juvenile Chinook salmon $O$. tshawytscha. We first determined if selected sampling methods (gill snip, fin clip, mucus scraping, blood draw, and kidney biopsy) were non-lethal to fish in a weight range between 3 and $15 \mathrm{~g}$. We then investigated the progression of $R$. salmoninarum infection by testing candidate non-lethal samples and lethal samples from fish exposed to the bacterium by immersion challenge. For the challenge experiment, we used 2 stocks of Chinook salmon that had been previously shown to exhibit significant differences in survival following $R$. salmoninarum laboratory injection challenges (Purcell et al. 2008, Metzger et al. 2010), to investigate possible effects of differing BKD susceptibility on the success of $R$. salmoninarum detection in non-lethal samples. Delayed or reduced occurrence of histopathological lesions in kidney tissues and a transient reduction in kidney bacterial load were observed in the higher survival Wisconsin stock in comparison with the lower survival progenitor stock from Washington state (Metzger et al. 2010), but it is not known if or how these differences might be reflected in parameters such as bacterial uptake, tissue tropism, proliferation and shedding following a more natural route of infection by immersion challenge. In the current research, candidate non-lethal samples (gill, fin, mucus, and blood) from each fish were tested for $R$. salmoninarum by both nonquantitative and quantitative PCR assays, and results were compared with those obtained by evaluation of lethal (kidney) samples from the same fish by culture, PCR, FAT, ELISA, and histopathology to assess infection status.

Several of the candidate non-lethal samples (gill, fin, and mucus) were taken from areas exposed to the external environment, with the possibility that passive association of $R$. salmoninarum shed into the water with the fish surface might significantly influence the presence and levels of the bacterium detected by PCR in these samples. We therefore used solid phase cytometry (SPC) (Vanhee et al. 2010) to detect and quantify $R$. salmoninarum in the water of holding tanks at several times after challenge. The SPC technology is superior to other methods such as epifluorescence microscopy and flow cytometry for detection and accurate enumeration of low numbers of target cells in fluid samples (Mignon-Godefroy et al. 1997, Lemarchand et al. 2001, Lisle et al. 2004), as was predicted to occur in this study.

The principal objectives of this research were to determine (1) if fin clips, gill snips, surface mucus scrapings, blood draws, or kidney biopsies could be obtained non-lethally from juvenile Chinook salmon O. tshawytscha within the tested weight range, (2) if any of the non-lethal samples tested could accurately discriminate between $R$. salmoninarum-exposed and non-exposed fish, and (3) whether any of the tested non-lethal samples could serve as a reasonable alternative to lethal kidney samples for assessment of $R$. salmoninarum infection intensity. Use of fish of known $R$. salmoninarum exposure status was considered essential for completion of this study.

\section{MATERIALS AND METHODS}

\section{Experimental fish}

Chinook salmon used in this research included a Lake Michigan (Great Lakes) stock from Strawberry Creek, Wisconsin (Wisconsin Department of Natural Resources, brood years 2005 and 2006), and a Puget Sound stock (Green River) from the Soos Creek Hatchery, Rainier Complex, Washington state (Washington Department of Fish and Wildlife, brood year 2006). To minimize vertical transmission of Renibacterium salmoninarum to progeny fish, which could confound experimental results, we screened spawning fish in these populations for $R$. salmoninarum prior to selection of egg lots for the research. This procedure has been used successfully to create groups of specific-pathogen-free (SPF) fish for multiple laboratory studies (Coady et al. 2006, Purcell et al. 2008, Metzger et al. 2010, Elliott et al. 2013). Kidney tissues from spawning male and female fish and ovarian fluids from females were screened by double polyclonal antibody ELISA (ELISA II; Pascho et al. 1991). In 2005, only fish with negative or low 
ELISA values were used to create progeny; ELISA categories were previously defined (Purcell et al. 2008). For fish spawned in 2006, ovarian fluid samples that tested negative by ELISA were further tested by membrane filtration-FAT (MF-FAT; Elliott \& McKibben 1997), and only spawning pairs with samples that tested negative by both ELISA and MF-FAT were used to create progeny groups. Eyed eggs from the selected families were transferred to the Western Fisheries Research Center, Seattle, Washington, where they were hatched and reared to the appropriate size and subjected to experimentation in single-pass sand-filtered, UV-treated Lake Washington water.

\section{Evaluation of candidate non-lethal sampling methods}

Survival of groups of juvenile Wisconsin Chinook salmon of 2 different sizes representing the 2005 and 2006 brood years was evaluated after candidate nonlethal sampling procedures were applied. The first group tested (Expt 1) had an average fork length $( \pm \mathrm{SD})$ of $109( \pm 13.8) \mathrm{mm}$ and an average weight of $15.2( \pm 5.3) \mathrm{g}$. The second group tested (Expt 2) consisted of fish with an average fork length of $66( \pm 7.6) \mathrm{mm}$ and an average weight of $2.8( \pm 0.9) \mathrm{g}$.

The survival study for each size group included the following treatment groups: (1) fish with a gill filament sample removed, (2) fish with a surface mucus sample removed, (3) fish with a sample of fin tissue removed, (4) fish with a blood sample taken, (5) fish with a kidney biopsy sample taken, (6) fish subjected to anesthesia only, and (7) non-anesthetized, unhandled control fish (no treatment). The fish for all groups except for the no treatment group were anesthetized with $15 \mathrm{mg} \mathrm{l}^{-1}$ of tricaine methanesulfonate (MS-222, Argent Chemical Laboratories) buffered to $\mathrm{pH} 7.0$ by the addition of $5 \mathrm{mg} \mathrm{l}^{-1}$ sodium bicarbonate, before sample collection. Sample collection of gill tissue followed the protocol for non-lethal gill filament sampling described by Schrock et al. (1994). A $2 \times 3 \mathrm{~mm}$ gill filament sample (5 to $10 \mathrm{mg}$ ) was removed from the first gill arch of each $15.2 \mathrm{~g}$ fish by use of surgical scissors. The gills of the $2.8 \mathrm{~g}$ fish were too small to obtain the correct size of gill filament, so the gill tissue amount was estimated. Surface mucus (5 to $10 \mathrm{mg}$ ) was removed by gentle scraping in an anterior-to-posterior direction, to minimize scale loss, with a plastic stir stick (Sarstedt) with the rounded tip cut to a flat surface. The mucus was removed dorsal to the lateral line by scraping 5 times. A $2 \times 3 \mathrm{~mm}$ sample of anal fin tissue (5 to $10 \mathrm{mg}$ ) was removed by use of surgical scissors. Each blood sample (20 to $50 \mu \mathrm{l}$ ) was taken from the caudal vessels of the $15.2 \mathrm{~g}$ fish by use of a $1 \mathrm{ml}$ syringe fitted with a 25 gauge, $2.2 \mathrm{~cm}$ heparinized needle. Blood samples were collected from caudal vessels of the $2.8 \mathrm{~g}$ fish by use of standard insulin needles and syringes (28 gauge, $1.3 \mathrm{~cm}$ needle, $0.5 \mathrm{ml}$ syringe). Kidney biopsies were performed as described by Noga et al. (1988). Briefly, the gill operculum was lifted and for the $15.2 \mathrm{~g}$ fish, a 25 gauge, $2.2 \mathrm{~cm}$ heparinized needle attached to a $1 \mathrm{ml}$ syringe was inserted dorsally and then dorsocaudally into the kidney, just caudal to the last branchial arch. The syringe was then aspirated to collect 20 to $50 \mu \mathrm{l}$ of kidney tissue. For the $2.8 \mathrm{~g}$ fish, standard insulin needles and syringes were used to collect kidney biopsies as described above. To ensure that kidney tissue was being sampled by this procedure, a separate group of 10 fish was subjected to the kidney biopsy procedure before the main sampling, and wet mounts of the aspirated material were examined microscopically for melanomacrophages, which are present in the kidney but not peripheral blood. The anesthesia-only group was anesthetized, weighed and measured, then placed into the tank. The non-anesthetized, unhandled fish (no treatment group) were counted into the tanks. Duplicate groups of 30 fish each were used for each treatment and were held in 2781 tanks at an average water temperature of 11.1 to $11.4^{\circ} \mathrm{C}$ for $30 \mathrm{~d}$ after sampling, and mortality was monitored.

\section{Comparison of non-lethal and lethal methods to monitor status of $\boldsymbol{R}$. salmoninarum infections}

R. salmoninarum immersion challenge. The $R$. salmoninarum isolate GL-64, cultured from the spleen of a diseased adult Lake Michigan Chinook salmon in 1990, was used for the challenge. The bacterium was cultured at $15^{\circ} \mathrm{C}$ for $7 \mathrm{~d}$ in KDM2 broth medium (Evelyn 1977), modified as described by Elliott et al. (2013). The culture was centrifuged and the pellet resuspended in sterile $0.01 \mathrm{M}$ phosphate-buffered saline (PBS), pH 7.4, containing $0.1 \%$ (w/v) peptone (PBS-peptone) diluent, and bacteria in the suspension were enumerated by MF-FAT prior to the challenge, according to procedures previously described by Purcell et al. (2008). Serial dilutions of the bacterial suspension were plated on KDM2 agar medium to determine the final viable count of $R$. salmoninarum in the challenge dose added to the tanks. 
A total of 300 Wisconsin Chinook salmon (2006 brood year, $35 \mathrm{~g}$ average weight) were acclimated to $15^{\circ} \mathrm{C}$ in four 5931 tanks (150 fish per duplicate tank) for $1 \mathrm{wk}$ in preparation for the challenge. A second group of 300 fish was acclimated similarly for a sham control challenge. Equivalent groups of fish were acclimated from the Washington Chinook salmon stock (2006 brood year, $35 \mathrm{~g}$ average weight). Five days prior to challenge, 10 fish were removed from each tank, and kidneys were tested by culture, ELISA and real-time quantitative PCR (qPCR) as described in the sections below, to confirm that fish were negative for $R$. salmoninarum.

The $24 \mathrm{~h} R$. salmoninarum immersion challenge was initiated by lowering the water level in the tanks to $148 \mathrm{l}$, and the flow was stopped. Each tank was supplied with oxygen throughout the challenge. A $740 \mathrm{ml}$ aliquot of the culture suspension was added to each of the replicate challenge tanks, which gave a final $R$. salmoninarum concentration of 6.77 $\log _{10}\left(\mathrm{CFU} \mathrm{m} \mathrm{m}^{-1}\right)$ added to each tank. The sham treatment tanks received an equivalent volume of PBS-peptone only. Water samples taken from each tank for culture about $1 \mathrm{~h}$ and $24 \mathrm{~h}$ after the beginning of the challenge verified that viable $R$. salmoninarum concentrations in the tanks ranged between 6.8 and $7.1 \log _{10}\left(\mathrm{CFU} \mathrm{ml} \mathrm{m}^{-1}\right)$ during the challenge (data not shown). At the end of the challenge, water flow was re-established and the levels allowed to rise to the normal tank volume.

Post-challenge sampling of fish. Fish were maintained at $15^{\circ} \mathrm{C}$ following the $R$. salmoninarum challenge, and were sampled at approximately $3 \mathrm{wk}$ intervals for testing by methods described below until Week 21 post-infection. Most samples consisted of 30 fish from each $R$. salmoninarum challenge group and 30 from each sham challenge group, with 15 fish taken from each duplicate tank.

Sampled fish were euthanized with an overdose of buffered MS-222 and subjected to 1 lethal sampling method (kidney removal) and 4 candidate non-lethal tissue sampling methods, including mucus scraping, pelvic fin clip, gill filament clip, and blood sample (as previously described for $15.2 \mathrm{~g}$ fish in 'Evaluation of candidate non-lethal sampling methods'). Separate instruments and gloves were used for sampling each fish to prevent cross-contamination. Target sample amounts were $10 \mu \mathrm{l}$ for blood and 5 to $10 \mathrm{mg}$ for fin, gill, and mucus. The samples were placed in preweighed tubes and frozen at $-80^{\circ} \mathrm{C}$ for DNA extraction and PCR testing.

After sub-samples were taken from the anterior and posterior kidney for histopathology, the remain- ing kidney tissue was removed and placed in a Whirl-Pak ${ }^{\circledR}$ bag (Nasco) for manual homogenization. Additional tissues were sampled for histopathology as described below. The homogenized kidney tissue was aliquoted into pre-weighed tubes for DNA extraction ( $25 \mathrm{mg})$ and ELISA ( 100 to $250 \mathrm{mg})$, and frozen at $-80^{\circ} \mathrm{C}$ for later analysis. The homogenized kidney samples for ELISA testing were diluted 1:8 $(\mathrm{w} / \mathrm{v})$ in $0.01 \mathrm{M}$ PBS, pH 7.4, containing $0.05 \%$ (by volume) Tween 20 (PBS-T20) before freezing. A FAT sample was taken by using a calcium alginate swab (Fisher Scientific), pre-moistened with sterile physiological saline, to remove a small amount of tissue from the bag and smear it on a 2-well FAT slide (Erie Scientific; $8 \mathrm{~mm}$ diameter wells). The remainder of the tissue was used for culture.

Culture. Kidney tissue from each sampled fish was cultured for detection and enumeration of R. salmoninarum by the protocol of Jansson et al. (1996) as modified from the method of Evelyn et al. (1981). Briefly, homogenized kidney tissue samples were diluted at $10 \mathrm{ml} \mathrm{g}^{-1}$ of tissue in PBS-peptone, vortex mixed and then centrifuged at $2500 \times g$ for 20 min at $4^{\circ} \mathrm{C}$. The supernatant was discarded and the pellet was resuspended at a 1:1 ratio (w/v) in PBS-peptone, and then a $10 \mu \mathrm{l}$ volume of the resuspended pellet was spread onto the entire surface of each of 2 selective kidney disease medium (SKDM) agar plates (Austin et al. 1983). Culture plates were incubated at $15^{\circ} \mathrm{C}$ for at least $6 \mathrm{wk}$, and $R$. salmoninarum colonies were counted and verified as described by Elliott et al. (2013).

Histopathology and immunohistochemistry. Tissues collected for histopathological analysis included the gill, anterior and posterior kidney, liver, gall bladder, spleen, pyloric ceca, pancreas, gastrointestinal tract, fin, and skin (with the latter 2 tissues taken from fish at the $15 \mathrm{wk}$ sample time and later). Kidney and gill tissues were taken from all sampled fish, and the other tissues were taken from the first 5 fish sampled from each tank. Samples were fixed in Carson's modified Millonig phosphate-buffered formalin (Carson et al. 1973) for $48 \mathrm{~h}$ and then transferred to $70 \%$ ethanol until processing and embedding in paraffin wax. Serial sections were cut at $4 \mu \mathrm{m}$ and collected on Superfrost ${ }^{\mathrm{TM}}$ slides (ThermoFisher Scientific) for standard Gill's hematoxylin and eosin (H\&E) staining, or on ProbeOn ${ }^{\mathrm{TM}}$ Plus slides (ThermoFisher Scientific) for immunohistochemistry. Tissues were examined by light microscopy with a Zeiss Axiophot microscope.

For immunohistochemical (IHC) detection and identification of $R$. salmoninarum, tissue sections were 
heated in a $55^{\circ} \mathrm{C}$ oven for $30 \mathrm{~min}$, dewaxed and rehydrated through decreasing concentrations of ethanol in deionized water. Proteolytic enzyme-induced epitope retrieval was performed by immersing sections in $37^{\circ} \mathrm{C}$ deionized water for $15 \mathrm{~min}$, followed by an overlay with protease Type XIV (Sigma Chemical; $0.5 \mathrm{mg} \mathrm{ml}^{-1}$ ) in Tris-buffered saline (TBS, $0.05 \mathrm{M}$ Tris/ $\mathrm{HCl}, 0.14 \mathrm{M} \mathrm{NaCl}, \mathrm{pH}$ 7.4) and incubation in a humid chamber for $15 \mathrm{~min}$ at $37^{\circ} \mathrm{C}$. The enzymatic reaction was terminated by soaking for $10 \mathrm{~min}$ in $4^{\circ} \mathrm{C}$ TBS. Subsequent incubations were performed in a humid chamber at room temperature followed by a wash step consisting of a brief rinse and $5 \mathrm{~min}$ immersion in TBS containing $0.05 \%$ (v/v) Tween ${ }^{\circledR} 20$ (Sigma-Aldrich). To inhibit non-specific background staining, tissues were incubated in Serum-Free Protein Block (Dako) for $10 \mathrm{~min}$. The blocking solution was then drained, not rinsed, from the slides. Bac Trace $^{\circledR}$ affinity-purified goat anti- $R$. salmoninarum antibody (Kirkegaard \& Perry Laboratories [KPL]) was rehydrated in $50 \%$ glycerol and diluted in TBS to a final concentration of $2 \mu \mathrm{g} \mathrm{ml} \mathrm{m}^{-1}$. Sections were incubated in $150 \mu \mathrm{l}$ of the primary antibody for 30 min then washed as previously described. IHC staining was performed with the LSAB+ System, Alkaline Phosphatase (Dako) according to the manufacturer's protocol. Sections were then incubated in biotinylated swine anti-goat, anti-mouse, anti-rabbit Ig secondary antibody (LSAB+/alkaline phosphatase link, Dako) for $15 \mathrm{~min}$. After washing, the sections were incubated in alkaline phosphatase-labeled streptavidin (Streptavidin-AP, Dako) for 15 min, washed, then incubated with Fuchsin+ substrate-chromogen solution (Dako) for $10 \mathrm{~min}$. Finally, sections were counterstained with Mayer's hematoxylin, dipped in $37 \mathrm{mM}$ ammonia water, rinsed in deionized water, and mounted with Faramount aqueous mounting medium (Dako). Quality control samples consisted of tissues from known $R$. salmoninarum-infected and non-infected Chinook salmon and were included with each staining run.

The IHC-stained sections of kidney and other tissues were examined microscopically for the presence of specific staining indicative of the presence of $R$. salmoninarum, and kidney tissues were scored for infection intensity. Evaluations of specific IHC staining of kidney were obtained from observations of the anterior kidney tissue and posterior kidney tubules, glomeruli, and interstitium. The evaluations included stain distribution (scale 0 to 3 ) and staining intensity (0 to 3). An overall score of kidney infection severity was obtained by adding scores for each area of the tissue.
ELISA. The ELISA II procedure of Pascho et al. (1991), which measures the levels of a soluble antigen fraction of $R$. salmoninarum, was used to test kidney samples. Unconjugated and horseradish peroxidase-conjugated polyclonal goat immunoglobulin to $R$. salmoninarum (KPL) and a positive control antigen (KPL) were used at the same concentrations previously described (Pascho et al. 1991). Negative control samples consisted of kidney tissue from known $R$. salmoninarum-negative fish. The kidney tissue samples, which had been diluted with PBS-T20 before storage as previously described, were heated at $100^{\circ} \mathrm{C}$ for $15 \mathrm{~min}$, followed by centrifugation at $10000 \times g$ for $6 \mathrm{~min}$ at $4^{\circ} \mathrm{C}$ before testing. Each sample was tested in duplicate, with $200 \mu$ of sample supernatant pipetted into each ELISA plate well. To select the negative-positive threshold absorbance or optical density (OD) value to maximize ELISA sensitivity and specificity, a receiver operating characteristic (ROC) curve was used to generate data for truepositive and false-positive detection rates at several potential cutoff OD values as described by Elliott et al. (2013); the cutoff (lowest ELISA-positive OD) was set at 0.095 .

Direct FAT (DFAT). Smears of homogenized kidney tissue were fixed and stained according to the procedure of Pascho et al. (1987) with modifications described by Elliott et al. (2013). A positive control slide with kidney tissue homogenate smears from a known $R$. salmoninarum-positive fish was included with each set of slides stained. Stained smears were observed by epifluorescence microscopy at 1000x magnification, with a total of 100 microscope fields examined per 2 -well slide (50 per well) in a non-overlapping grid pattern. Intact, labeled bacterial cells showing size and morphological features consistent with $R$. salmoninarum were counted.

DNA extraction for PCR. A DNeasy blood and tissue kit (Qiagen) was used to extract DNA from all samples, following the manufacturer's instructions for gram-positive bacteria as described by Chase et al. (2006). A $10 \mu$ l volume of blood sample was subjected to extraction, and the weight of each kidney, gill, mucus, and fin sample was calculated prior to extraction using the known weight of each empty sample tube. The DNA from each sample was eluted with $200 \mu \mathrm{l}$ of buffer AE (Qiagen). Negative extraction controls containing reagents only were processed concurrently with samples to verify that each extraction was free of contaminating DNA.

Nested PCR (nPCR). The nPCR used was designed to detect a 320 base pair (bp) region of the $R$. salmoninarum gene encoding the major soluble antigen 
(MSA) (Chase \& Pascho 1998). The nPCR procedure of Pascho et al. (1998) was used, with modifications as described by Elliott et al. (2013). Samples giving equivocal results were re-tested. Controls for each nPCR run included the negative extraction control described above, a negative PCR control without template DNA, and a positive control consisting of DNA extracted from an $R$. salmoninarum culture.

qPCR. The qPCR assay targeted a $69 \mathrm{bp}$ region of the msa gene (Chase et al. 2006) and was conducted using an ABI 7900HT sequence detection system (Applied Biosystems) according to the method described by Elliott et al. (2013; qPCR \#1 procedure), except that TaqMan ${ }^{\circledR}$ Gene Expression Master Mix (Applied Biosystems) was substituted for TaqMan ${ }^{\circledR}$ Universal Master Mix (Applied Biosystems) for all samples except blood. Controls were the same as described for nPCR. For quantification of the amount of $R$. salmoninarum DNA in a sample, serially diluted $R$. salmoninarum representing a range of 5 to $5 \times$ $10^{5}$ cells per reaction was used to construct a standard curve (Chase et al. 2006). Standard curve analyses were performed in triplicate, and samples were run in duplicate. A sample was considered positive if both replicates showed amplification and the mean cycle threshold $\left(C_{\mathrm{T}}\right)$ value was less than 38 , representing the theoretical lower limit of consistent detection ( $\geq 5 R$. salmoninarum cells per reaction; Chase et al. 2006).

Testing of water samples by SPC. Before each fish sampling, a $500 \mathrm{ml}$ water sample was taken from each tank, subsampled by taking three $15 \mathrm{ml}$ aliquots, and frozen at $-80^{\circ} \mathrm{C}$ until used for enumeration of $R$. salmoninarum by SPC. Triplicate samples were prepared for SPC testing as follows. As a primary antibody, the SPC procedure used unlabeled, affinity purified goat anti- $R$. salmoninarum polyclonal antibody (KPL), rehydrated according to the manufacturer's instructions, then diluted to a concentration of $1.5 \mu \mathrm{g} \mathrm{ml}^{-1}$ in $0.01 \mathrm{M}$ PBS, $\mathrm{pH} 7.1$ containing $0.05 \%(\mathrm{v} / \mathrm{v})$ Tween $20($ PBS-T20) and $2 \%(\mathrm{v} / \mathrm{v})$ normal donkey serum (Sigma-Aldrich). The secondary antibody used, Alexa Fluor 488-labeled anti-goat polyclonal antibody (produced in donkey; Invitrogen), was diluted to a working concentration of $5 \mu \mathrm{g}$ $\mathrm{ml}^{-1}$ in PBS-T20, and Evans blue was added at a final concentration of $0.01 \%(\mathrm{v} / \mathrm{v})$. All reagents and diluents were filtered through syringe filters of $0.2 \mu \mathrm{m}$ pore size just before use, and the antibodies were further centrifuged at $16000 \times g$ for $30 \mathrm{~min}$ at $4^{\circ} \mathrm{C}$.

To prepare samples for SPC, a $0.5 \mathrm{ml}$ volume of PBS-T20 was added to each $1 \mathrm{ml}$ water sample, followed by vortex mixing. The sample was then filtered under vacuum through a $0.4 \mu \mathrm{m}$ pore size, $25 \mathrm{~mm}$ diameter polyester membrane filter (ChemFilter CB 0.4, bioMérieux), and rinsed under vacuum with $2 \mathrm{ml}$ PBS-T20. To inhibit non-specific staining, the filter surface was flooded for 2 min with $600 \mu \mathrm{l}$ of a blocking solution consisting of $10 \%(\mathrm{v} / \mathrm{v})$ normal donkey serum in PBS-T20. The blocking solution was removed by gentle vacuum, then the filter was removed from the vacuum holder, placed onto a fresh pool of $300 \mu \mathrm{l}$ blocking solution in a small covered dish and incubated for $20 \mathrm{~min}$ at $30^{\circ} \mathrm{C}$. Without rinsing, the membrane filter was then placed onto $80 \mu \mathrm{l}$ of primary antibody that had been pipetted into an Analyslide ${ }^{\mathrm{TM}}$ dish (Pall Corporation), and incubated covered for $1 \mathrm{~h}$ at $30^{\circ} \mathrm{C}$. The filter was rinsed with PBS-T20 under vacuum as previously described, then placed onto $70 \mu \mathrm{l}$ of secondary antibody that had been pipetted into an Analyslide dish, and incubated covered for $1.5 \mathrm{~h}$ at $30^{\circ} \mathrm{C}$. Following a final PBS-T20 rinse under vacuum, the filter was mounted onto a scanning holder for analysis by SPC. For mounting, a ScanRDI filter support pad (bioMérieux) was placed on the metal scanning holder and saturated with $100 \mu \mathrm{l}$ of PBS, pH 7.1, containing $20 \%$ $(\mathrm{v} / \mathrm{v})$ glycerol, and the membrane filter was then placed on the support pad.

The mounted filter was transferred to a solid-phase cytometer (ScanRDI, bioMérieux) and scanned according to the manufacturer's instructions. Subsequently, the fluorescent signals produced were processed by a computer to differentiate valid signals (labeled $R$. salmoninarum cells) from background noise (electronic, optical, or autofluorescent particles) based on a series of software discriminants (Jones et al. 1999, Vanhee et al. 2010). For visual verification of results, the filter holder was transferred to an epifluorescence microscope (Olympus BX51) with a motorized stage linked to the cytometer computer (Vanhee et al. 2010).

Statistical analysis. Statistical analyses were accomplished using InStat v3 (GraphPad Software) and IBM SPSS v18 (IBM). To assess survival following application of candidate non-lethal sampling procedures, survival curves for each tank were estimated by the Kaplan-Meier method and curves were compared by log-rank analysis. As no significant differences in replicate tanks were observed, replicates were pooled and survival curves for each treatment group were compared by log-rank analysis. For this and other comparisons, results were considered significant at $\mathrm{p}$ values $<0.05$.

Fisher's exact test was used for evaluation of differences in $R$. salmoninarum prevalence between 2 
groups, and differences among 3 or more groups were analyzed by the chi-square test. Estimates of diagnostic sensitivity and specificity from PCR testing of candidate non-lethal samples, likelihood ratios (LRs) for positive and negative test results, and 95\% confidence intervals (CI) were calculated as described by Thrusfield (2007). A LR value $>10$ for a positive test was considered robust evidence that the result came from an infected fish instead of an uninfected fish, and a LR value $<0.1$ for a negative test was considered strong evidence that the result came from an uninfected rather than infected fish (Akobeng 2007). The diagnostic odds ratio (DOR) and $95 \%$ CI were calculated for nPCR and qPCR results with each sample type to determine the ratio of the odds of $R$. salmoninarum infection in positive test results over the odds of infection in negative test results (Caraguel et al. 2011). Concordance analysis was used to assess the proportion of test results (positive or negative) on which 2 different assays agreed, and the $\kappa$-statistic was calculated to express the proportion of potential agreement beyond chance (Smith 2006).

For comparison of $R$. salmoninarum levels between or among assays, sample types, fish stocks, or sample times, the data generated by quantitative and semiquantitative assays were evaluated by a nonparametric Mann-Whitney test (2 groups), or the KruskalWallis test (3 or more groups). Dunn's multiple comparison test was applied when a significant result $(p<0.05)$ was observed using the Kruskal-Wallis test. Spearman's rank correlation analysis was employed to test for correlations between $R$. salmoninarum levels estimated by individual quantitative and semiquantitative assays in challenged fish that tested positive. Values used for correlation analysis included ELISA, OD $405 \mathrm{~nm}$ i culture, $\log _{10}\left(\mathrm{CFU} \mathrm{g}{ }^{-1}\right)$; kidney or non-lethal sample $\mathrm{qPCR}, \log _{10}(R$. salmoninarum cells $\left.\mathrm{g}^{-1}\right)$; DFAT, $\log _{10}(R$. salmoninarum cells per 100 microscope fields) at $1000 \times$ magnification; and $\mathrm{IHC}, \log _{10}(R$. salmoninarum infection severity score); $\log$-transformed values were $\log (x+1)$.

As a single gold standard assay has not been identified for detection and quantification of R. salmoninarum (Elliott et al. 2013), and researchers have reported that use of data from more than 1 assay can provide complementary information resulting in improved assessment of $R$. salmoninarum infection status or stage (White et al. 1996, Elliott et al. 1997, Bruno et al. 2007, Faisal \& Eissa 2009, Nance et al. 2010), we employed composite reference standards (Naaktgeboren et al. 2013) for comparison of results between lethal kidney assays and non-lethal assays in addition to the comparisons between individual assays previously described. The kidney assays we used differ in estimated diagnostic sensitivity (Elliott et al. 2013, Kent et al. 2013), and results from these assays generally show greater concordance and correlation as infection intensity increases (Powell et al. 2005, Bruno et al. 2007, Nance et al. 2010, Elliott et al. 1997, 2013, Arnason et al. 2013), with the highest agreement observed for severe active infections. Therefore, to determine if changes in $R$. salmoninarum detection rates by either nPCR or qPCR testing of candidate non-lethal samples reflected changes in infection stage as assessed by kidney sample testing, each $R$. salmoninarum-challenged fish was assigned to an infection stage category based on the number of kidney assays that yielded positive results for that fish (mild infection $=1$ to 2 assays positive, moderate infection $=3$ to 4 assays positive, severe infection $=5$ to 6 assays positive). To further evaluate correlations between kidney $R$. salmoninarum infection intensity and quantity estimates $\left(\log _{10}[R\right.$. salmoninarum cells $\mathrm{g}^{-1}$ ]) obtained from testing of candidate non-lethal samples by qPCR, a composite kidney infection intensity score for each fish was calculated by adding values from the quantitative and semi-quantitative kidney assay results. The individual values comprising the kidney infection intensity score were the same as described (previous paragraph) for analysis of correlations between results of individual assays. Spearman's rank correlation analysis was used to test for significance of correlations.

\section{RESULTS}

\section{Survival of fish subjected to candidate non-lethal sampling methods}

Post-sampling mortality for both experiments was highest in the kidney biopsy and blood draw treatment groups $(\geq 5 \%$; Table 1$)$. No fish in the mucus scraping and gill snip treatments died in either experiment, whereas a single fish in the fin clip treatment group died in each experiment (Table 1). In Expt 1 (15.2 g fish), no significant differences in survival ( $p>0.05$ ) were observed among the treatment and control groups. Mortality in some groups in this experiment (blood draw, kidney biopsy and no treatment control) was affected by pre-existing tail rot of unknown etiology that also occurred in the stock tanks and was therefore not considered to be associated with a particular treatment. Mortalities with clinical signs of tail rot in Expt 1 were cen- 
Table 1. Summary of mortality $30 \mathrm{~d}$ after application of candidate non-lethal sampling methods to Chinook salmon Oncorhynchus tshawytscha with differing mean weights from 2 year classes

\begin{tabular}{|lcc|}
\hline \multirow{2}{*}{ Treatment } & \multicolumn{2}{c|}{ No. dead/total (\%) } \\
& $15.2 \mathrm{~g}$ fish & $2.8 \mathrm{~g}$ fish \\
\hline Anesthesia + mucus scrape & $0 / 60(0)$ & $0 / 60(0)$ \\
Anesthesia + fin clip & $1 / 60(2)$ & $1 / 60(2)$ \\
Anesthesia + gill snip & $0 / 60(0)$ & $0 / 60(0)$ \\
Anesthesia + blood draw & $3 / 59^{\mathrm{a}}(5)$ & $5 / 60(8)$ \\
Anesthesia + kidney biopsy & $3 / 55^{\mathrm{a}}(5)$ & $18 / 60(30)$ \\
MS-222 anesthesia only & $0 / 60(0)$ & $0 / 60(0)$ \\
No treatment & $0 / 57^{\mathrm{a}}(0)$ & $0 / 60(0)$ \\
aFish that died with obvious & signs of tail rot (unknown \\
etiology) were censored for the survival analysis and are & \\
not shown in the totals & & \\
\end{tabular}

sored for the survival analysis. In Expt 2 (2.8 $\mathrm{g}$ fish), survival in the no treatment and anesthesia control groups was significantly higher than that in the blood draw and kidney biopsy treatment groups $(p=0.02$ and $p<0.0001$, respectively). Survival of fish in the kidney biopsy treatment group was lower than that in all other treatment groups $(\mathrm{p} \leq 0.002$ for all pairwise comparisons). Survival in the blood draw treatment group was lower than that in all other treatment groups $(p \leq 0.02)$ except the fin clip group $(\mathrm{p}=0.10)$.

The kidney biopsy procedure resulted in variable-sized rectangular zones of dark skin pigmentation, indicative of nerve damage, which appeared within 5 to 10 min after biopsy in both experiments. The dark pigmented areas were located on the head and body above the lateral line, and affected up to $90 \%$ of the fish in a group. The dark pigmentation gradually faded during the $30 \mathrm{~d}$ holding period but was still visible in some fish at the termination of the experiment. About $30 \%$ of the fish in the blood sample group in Expt 2 showed similar dark pigmentation in the area where the needle was inserted.

Due to the small size of the Expt 2 fish, it was difficult to obtain the desired sample size (weight) of gill tissue from each fish. The gill sampling caused several of the fish to bleed profusely; however, no mortality occurred in this group.

\section{Progression of Renibacterium salmoninarum infection (kidney sample testing)}

Grossly visible lesions suggestive of BKD were not common and consisted of slight unilateral exophthalmos or ascites observed in about $7 \%$ of $R$. salmoninarum-exposed fish sampled after challenge (data not shown). The prevalence of viable $R$. salmoninarum in kidney tissue of fish after challenge, as determined by bacteriological culture, was variable, but prevalence was $50 \%$ or higher in both the Wisconsin and Washington stocks from Week 3 through Week 12 post-challenge, and decreased to less than $50 \%$ in both stocks from Week 15 through Week 21 post-challenge (Fig. 1). No R. salmoninarum-positive fish were detected by kidney culture among shamchallenged controls. The $R$. salmoninarum prevalence determined by culture was significantly higher $(p=0.03)$ in the Wisconsin stock than in the Washington stock at Week 3 , and was significantly higher $(\mathrm{p}=$ 0.01 ) in the Washington stock than in the Wisconsin stock at Week 12 (Fig. 1, Table 2), but there were no significant differences $(\mathrm{p}>0.05)$ in prevalence between the stocks at any other time point. For both stocks combined, $R$. salmoninarum prevalence by

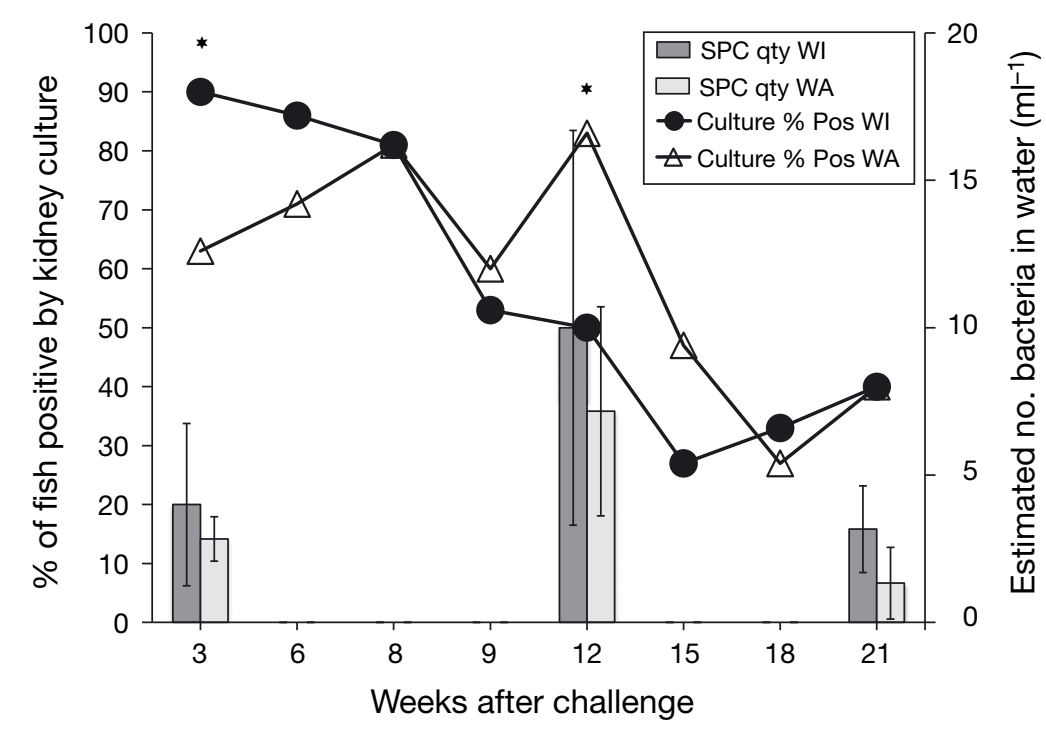

Fig. 1. Prevalence of Renibacterium salmoninarum determined by bacteriological culture in juvenile Chinook salmon Oncorhynchus tshawytscha from 2 stocks, Great Lakes, Wisconsin (WI) and Soos Creek, Washington (WA), sampled at various times after an immersion challenge with $R$. salmoninarum (lines), and mean $R$. salmoninarum concentrations ( \pm SD of 6 water samples) measured by solid phase cytometry (SPC) in the tank water at 3 sample times after challenge (bars). Thirty fish were sampled from each stock for bacteriological culture at all time points after challenge except Week 6 (14 fish per stock) and Week 8 (16 fish per stock). ${ }^{*}$ Significant difference in $R$. salmoninarum prevalence $(\mathrm{p} \leq 0.03)$ between the WI and WA salmon stocks 
Table 2. Prevalence of Renibacterium salmoninarum $(R s)$ detected by ELISA, bacteriological culture, nPCR, qPCR, direct fluorescent antibody test (DFAT), and immunohistochemistry (IHC) in kidney tissue samples from 2 stocks of Chinook salmon Oncorhynchus tshawytscha challenged by immersion with $R$. salmoninarum, and mean infection or antigen levels detected by quantitative and semi-quantitative assays. Equivalent sham-challenge control fish were also tested (data not presented). Asterisks $\left({ }^{*}\right)$ in a column indicate significant differences $(\mathrm{p}<0.05)$ in $R$. salmoninarum prevalence or levels between fish stocks detected by an assay at a given sample time. For the combined fish stocks, values within a row not sharing a common uppercase letter indicate significant differences $(p<0.05)$ in $R$. salmoninarum prevalence or levels detected by an assay at different sample times. Units for infection or antigen level: ELISA, OD 405 nm; culture, $\log _{10}\left(\mathrm{CFU} \mathrm{g}{ }^{-1}\right) ; \mathrm{qPCR}, \log _{10}\left(R s\right.$ cells $\left.\mathrm{g}^{-1}\right)$; DFAT, $\log _{10}\left(R s\right.$ cells per 100 microscope fields) at $1000 \times$ magnification; $\mathrm{IHC}_{1} \log _{10}(R s$ infection severity score) (distribution and intensity of IHC staining in areas of the anterior and posterior kidney; scoring procedure explained in text)

\begin{tabular}{|c|c|c|c|c|}
\hline \multirow{2}{*}{$\begin{array}{l}\text { Assay } \\
\text { and } \\
\text { fish stock }\end{array}$} & \multicolumn{4}{|c|}{$\begin{array}{l}\text { No. (\%) of fish positive [Infection or antigen level, } \\
\text { mean } \pm \text { SD] }\end{array}$} \\
\hline & Week 3 & Week 12 & Week 21 & Total \\
\hline \multicolumn{5}{|l|}{ ELISA } \\
\hline Wisconsin & $\begin{array}{c}30(100)^{\mathrm{a}} \\
{[1.25 \pm 0.47]}\end{array}$ & $\begin{array}{c}30(100) \\
{[1.22 \pm 0.48]}\end{array}$ & $\begin{array}{c}30(100) \\
{[0.76 \pm 0.32]}\end{array}$ & $\begin{array}{c}90(100) \\
{[1.07 \pm 0.48]}\end{array}$ \\
\hline Washington & $\begin{array}{l}30(100) \\
{[1.26 \pm 0.36]}\end{array}$ & $\begin{array}{l}30(100) \\
{[0.99 \pm 0.45]}\end{array}$ & $\begin{array}{l}30(100) \\
{[0.89 \pm 0.28]}\end{array}$ & $\begin{array}{c}90(100) \\
{[1.05 \pm 0.40]}\end{array}$ \\
\hline $\begin{array}{l}\text { Combined } \\
\text { stocks }\end{array}$ & $\begin{array}{c}60(100)^{\mathrm{A}} \\
{[1.26 \pm 0.42]^{\mathrm{A}}}\end{array}$ & $\begin{array}{c}60(100)^{\mathrm{A}} \\
{[1.10 \pm 0.47]^{\mathrm{A}}}\end{array}$ & $\begin{array}{c}60(100)^{\mathrm{A}} \\
{[0.82 \pm 0.31]^{\mathrm{B}}}\end{array}$ & $\begin{array}{c}180(100) \\
{[1.06 \pm 0.44]}\end{array}$ \\
\hline \multicolumn{5}{|l|}{ Culture } \\
\hline Wisconsin & $\begin{array}{c}27(90)^{*} \\
{[3.68 \pm 0.72]}\end{array}$ & $\begin{array}{c}15(50)^{*} \\
{[3.22 \pm 1.02]}\end{array}$ & $\begin{array}{c}12(40) \\
{[3.60 \pm 0.98]}\end{array}$ & $\begin{array}{c}54(60) \\
{[3.54 \pm 0.88]}\end{array}$ \\
\hline Washington & $\begin{array}{l}19(63)^{*} \\
{[3.54 \pm 0.96]}\end{array}$ & $\begin{array}{l}25(83)^{*} \\
{[3.18 \pm 0.88]}\end{array}$ & $\begin{array}{c}12(40) \\
{[3.75 \pm 0.92]}\end{array}$ & $\begin{array}{c}56(62) \\
{[3.42 \pm 0.93]}\end{array}$ \\
\hline $\begin{array}{l}\text { Combined } \\
\text { stocks }\end{array}$ & $\begin{array}{c}46(77)^{\mathrm{A}} \\
{[3.62 \pm 0.82]^{\mathrm{A}}}\end{array}$ & $\begin{array}{c}40(67)^{\mathrm{A}} \\
{[3.19 \pm 0.92]^{\mathrm{A}}}\end{array}$ & $\begin{array}{c}24(40)^{\mathrm{B}} \\
{[3.67 \pm 0.94]^{\mathrm{A}}}\end{array}$ & $\begin{array}{c}110(61) \\
{[3.48 \pm 0.90]}\end{array}$ \\
\hline \multicolumn{5}{|l|}{ nPCR } \\
\hline Wisconsin & $18(60)^{\mathrm{b}}$ & $13(43)$ & $16(53)$ & $47(52)$ \\
\hline Washington & $10(33)^{b}$ & $21(70)$ & $12(40)^{\mathrm{b}}$ & 43 (48) \\
\hline $\begin{array}{l}\text { Combined } \\
\text { stocks }\end{array}$ & $28(47)^{\mathrm{A}}$ & $34(57)^{\mathrm{A}}$ & $28(47)^{\mathrm{A}}$ & $90(50)$ \\
\hline \multicolumn{5}{|l|}{ qPCR } \\
\hline Wisconsin & $\begin{array}{c}15(50) \\
{[5.01 \pm 0.90]}\end{array}$ & $\begin{array}{c}10(30) \\
{[5.39 \pm 1.59]}\end{array}$ & $\begin{array}{c}7(23) \\
{[5.23 \pm 1.97]}\end{array}$ & $\begin{array}{c}32(36) \\
{[5.18 \pm 1.37]}\end{array}$ \\
\hline Washington & $\begin{array}{c}7(23) \\
{[4.71 \pm 0.87]}\end{array}$ & $\begin{array}{c}14(47) \\
{[5.08 \pm 1.76]}\end{array}$ & $\begin{array}{c}9(30) \\
{[5.09 \pm 1.59]}\end{array}$ & $\begin{array}{c}30(33) \\
{[5.06 \pm 1.56]}\end{array}$ \\
\hline $\begin{array}{l}\text { Combined } \\
\text { stocks }\end{array}$ & $\begin{array}{c}22(37)^{\mathrm{A}} \\
{[4.92 \pm 0.88]^{\mathrm{A}}}\end{array}$ & $\begin{array}{c}24(40)^{\mathrm{A}} \\
{[5.20 \pm 1.67]^{\mathrm{A}}}\end{array}$ & $\begin{array}{c}16(27)^{\mathrm{A}} \\
{[5.16 \pm 1.70]^{\mathrm{A}}}\end{array}$ & $\begin{array}{c}62(34) \\
{[5.12 \pm 1.46]}\end{array}$ \\
\hline \multicolumn{5}{|l|}{ DFAT } \\
\hline Wisconsin & $\begin{array}{c}5(17) \\
{[0.59 \pm 0.50]}\end{array}$ & $\begin{array}{c}9(30) \\
{[0.80 \pm 0.65]}\end{array}$ & $\begin{array}{c}4(13) \\
{[0.95 \pm 0.94]}\end{array}$ & $\begin{array}{c}18(20) \\
{[0.78 \pm 0.66]}\end{array}$ \\
\hline Washington & $\begin{array}{c}1(3)^{\mathrm{c}} \\
{[0.48]}\end{array}$ & $\begin{array}{c}13(43) \\
{[0.78 \pm 0.73]}\end{array}$ & $\begin{array}{c}4(13) \\
{[0.85 \pm 0.98]}\end{array}$ & $\begin{array}{c}18(20) \\
{[0.78 \pm 0.74]}\end{array}$ \\
\hline $\begin{array}{l}\text { Combined } \\
\text { stocks }\end{array}$ & $\begin{array}{c}6(10)^{\mathrm{B}} \\
{[0.57 \pm 0.45]^{\mathrm{A}}}\end{array}$ & $\begin{array}{c}22(37)^{\mathrm{A}} \\
{[0.79 \pm 0.68]^{\mathrm{A}}}\end{array}$ & $\begin{array}{c}8(13)^{\mathrm{B}} \\
{[0.90 \pm 0.89]^{\mathrm{A}}}\end{array}$ & $\begin{array}{c}36(20) \\
{[0.78 \pm 0.69]}\end{array}$ \\
\hline \multicolumn{5}{|l|}{ IHC } \\
\hline Wisconsin & $\begin{array}{c}4(13) \\
{[0.98 \pm 0.28]}\end{array}$ & $\begin{array}{c}3(10) \\
{[1.17 \pm 0.44]}\end{array}$ & $\begin{array}{c}2(7) \\
{[0.99 \pm 0.73]}\end{array}$ & $\begin{array}{c}9(10) \\
{[1.05 \pm 0.39]}\end{array}$ \\
\hline Washington & $\begin{array}{c}4(13) \\
{[1.06 \pm 0.15]}\end{array}$ & $\begin{array}{c}4(13) \\
{[1.12 \pm 0.50]}\end{array}$ & $\begin{array}{c}1(3) \\
{[1.54]}\end{array}$ & $\begin{array}{c}9(10) \\
{[1.14 \pm 0.36]}\end{array}$ \\
\hline $\begin{array}{l}\text { Combined } \\
\text { stocks }\end{array}$ & $\begin{array}{c}8(13)^{\mathrm{A}} \\
{[1.02 \pm 0.21]^{\mathrm{A}}}\end{array}$ & $\begin{array}{c}7(12)^{\mathrm{A}} \\
{[1.14 \pm 0.44]^{\mathrm{A}}}\end{array}$ & $\begin{array}{c}3(5)^{\mathrm{A}} \\
{[1.18 \pm 0.61]^{\mathrm{A}}}\end{array}$ & $\begin{array}{c}18(10) \\
{[1.09 \pm 0.37]}\end{array}$ \\
\hline \multicolumn{5}{|c|}{$\begin{array}{l}\text { aOne sham-challenged control fish tested ELISA-positive } \\
{ }^{\mathrm{b}} \text { One sham-challenged control fish tested nPCR-positive } \\
{ }^{\mathrm{c} O n e ~ s h a m-c h a l l e n g e d ~ c o n t r o l ~ f i s h ~ t e s t e d ~ D F A T-p o s i t i v e ~}\end{array}$} \\
\hline
\end{tabular}

kidney culture was significantly higher at Week $3(\mathrm{p}<0.0001)$ and Week $12(\mathrm{p}=0.006)$ relative to Week 21 (Table 2).

Bacteriological culture results from kidney samples were used to select 3 time points - Weeks 3, 12, and 21 post-challenge - from which samples were processed and tested by the non-culture assays. Testing of kidney samples by non-culture assays at these 3 time points showed no significant differences $(\mathrm{p}>0.05)$ in $R$. salmoninarum prevalence between the 2 fish stocks at any single time point, but, similar to culture, testing by nPCR, qPCR, and DFAT showed a trend toward higher prevalence in Wisconsin fish at Week 3 and in Washington fish at Week 12 (Table 2). For both stocks combined, the highest $R$. salmoninarum prevalence was detected by most of the non-culture tests at Week 12, although DFAT was the only assay showing a significantly higher detection rate at Week 12 compared to Weeks $3(\mathrm{p}=0.001)$ and 21 ( $\mathrm{p}=0.006)$ (Table 2).

Overall, the highest $R$. salmoninarum prevalence in kidney samples from challenged fish was detected by ELISA, followed by culture, nPCR, qPCR, DFAT, and IHC (Table 2). Estimates of diagnostic sensitivity (95\% CI) for each kidney assay were: ELISA $1.00(0.97,1.00)$, culture 0.61 (0.54, 0.68), nPCR 0.50 (0.43, 0.57), qPCR 0.35 (0.28, 0.42), DFAT 0.20 $(0.15,0.27)$, and IHC $0.10(0.07,0.16)$. When test results for the 3 sample time points were combined, no significant differences in $R$. salmoninarum prevalence between the Wisconsin and Washington fish stocks were detected by any of the assays. False positive test results from kidney samples of sham-challenged control fish were rare, and included 1 sample each testing positive by ELISA and DFAT, and 3 samples testing positive by nPCR (Table 2).

Estimates of $R$. salmoninarum infection intensity were obtained by 
testing kidney samples from $R$. salmoninarumchallenged fish by quantitative (culture and qPCR) and semi-quantitative (ELISA and DFAT) assays (Table 2); intensity estimates varied depending on the analytes detected by the assays and the detection limits and ranges of each assay. For $R$. salmoninarum-positive fish, ELISA values ranged from OD 0.200 to 2.388 ; culture counts ranged from 2.30 to $4.78 \log _{10}\left(\mathrm{CFU} \mathrm{g}^{-1}\right)$, qPCR quantity estimates ranged from 3.79 to $10.17 \log _{10}\left(\right.$ cells $g^{-1}$ ), and DFAT counts ranged from 0.30 to $2.30 \log _{10}$ (cells per 100 microscope fields). There were no significant differences in $R$. salmoninarum levels in kidney samples from fish testing positive by ELISA, culture or qPCR between the Wisconsin and Washington stocks at any single time point (Table 2). When data for both stocks were combined, ELISA testing showed significantly higher $R$. salmoninarum antigen levels in fish sampled at Weeks $3(\mathrm{p}<0.001)$ and $12(\mathrm{p}<$ 0.01) post-challenge compared with fish sampled at Week 21 (Table 2). No significant differences in $R$. salmoninarum levels in the combined stocks among sample time points were detected by culture or qPCR ( $p>0.05$ ). Pairwise correlation analysis showed positive correlations between values obtained by kidney ELISA, culture, qPCR, and DFAT. Spearman's rank correlation coefficients $\left(r_{S}\right)$ for all comparisons were $\geq 0.47$, and were considered significant ( $\mathrm{p} \leq 0.0005)$ (data not shown).

\section{Histopathological evaluation of internal organs}

Among the 18 fish that tested positive for $R$. salmoninarum in kidney samples by IHC, $\log _{10}$ infection severity scores ranged from 0.48 to 1.58 , with 9 fish showing $\log _{10}$ scores indicative of mild infections (0.48 to 0.99$), 4$ showing moderate infections (1.00 to 1.46), and 5 showing severe infections $(\geq 1.47)$. Pairwise correlation analysis between kidney IHC scores and values from other quantitative and semi-quantitative kidney assays (ELISA, culture, qPCR and DFAT) showed significant positive correlations $\left(r_{S} \geq 0.71, p \leq 0.002\right)$ between the results of IHC and all the other assays except culture (data not shown). In addition to the focal to diffuse granulomatous inflammation observed in kidneys of some $R$. salmoninarum-challenged fish, focal accumulations of macrophages suggestive of $R$. salmoninarum infections were observed by histopathology in the kidneys of some sham-challenged control fish. However, the only changes of this nature that were confirmed as $R$. salmoninarum infections by IHC occurred in the $R$. salmoninarumchallenged fish.

Other internal organs had been sampled from 11 of the $18 R$. salmoninarum-challenged fish with kidneys testing positive for $R$. salmoninarum antigen by IHC, and one or more visceral organs from 5 of these fish also tested IHC-positive, indicative of more systemic infections. Visceral organs testing IHC-positive included spleen (5 fish), liver (4 fish), gall bladder (2 fish), pancreas (2 fish), and gastrointestinal tract (2 fish). R. salmoninarum antigen was only detected by IHC in other internal organs from fish that also tested IHC-positive in kidney tissue, but these organs had been sampled from only one-third (60) of the 180 R. salmoninarum-challenged fish from which kidneys were sampled.

\section{Evidence of bacterial shedding (water sample testing)}

Water testing by SPC at Weeks 3, 12, and 21 after challenge demonstrated low concentrations of $R$. salmoninarum cells (mean $\leq 10$ bacteria $\mathrm{ml}^{-1}$ ) in water sampled from all tanks in which $R$. salmoninarumchallenged fish were being held (Fig. 1). The R. salmoninarum concentrations were consistently higher in tanks holding Wisconsin fish compared with tanks holding Washington fish at each sample time point, but the differences were not significant $(p>0.05)$. Concentrations of $R$. salmoninarum detected in tank water by SPC were highest at Week 12 (Fig. 1), and significantly higher at Week 12 than at Week 21 for both the Wisconsin samples $(\mathrm{p}<0.05)$ and Washington samples $(\mathrm{p}<0.05)$. We also used MF-FAT to enumerate $R$. salmoninarum cells in water and saw similar patterns to those observed with SPC, but the overall detection rate was lower than that by SPC (methods and results not presented).

\section{Detection of $R$. salmoninarum in candidate non-lethal samples}

R. salmoninarum DNA was detected by PCR in mucus, gill, and fin samples from more than $50 \%$ of fish that had been challenged with the bacterium (Table 3). Among these sample types, the highest $R$. salmoninarum prevalence in challenged fish was detected by mucus nPCR (98\%), followed by mucus qPCR (92\%), gill nPCR (86\%), fin nPCR (76\%), gill qPCR (72\%), and fin qPCR (51\%). Very low R. salmoninarum detection rates were observed in blood 
Table 3. Prevalence of Renibacterium salmoninarum $(R s)$ detected by nPCR and qPCR in candidate non-lethal samples from 2 stocks of Chinook salmon Oncorhynchus tshawytscha challenged by immersion with $R$. salmoninarum, and mean $R$. salmoninarum quantity estimates determined by qPCR testing. Prevalence data only are shown for sham-challenged fish. Asterisks $\left({ }^{*}\right)$ in a column indicate significant differences $(p<0.05)$ in $R$. salmoninarum prevalence or levels between fish stocks detected by an assay at a given sample time or for all sample times combined. For the combined fish stocks, values within a row not sharing a common uppercase letter indicate significant differences $(\mathrm{p}<0.05)$ in $R$. salmoninarum prevalence or levels detected by an assay at different sample times

\begin{tabular}{|c|c|c|c|c|c|}
\hline \multirow{2}{*}{$\begin{array}{l}\text { Sample type, } \\
\text { assay and } \\
\text { fish stock }\end{array}$} & \multicolumn{4}{|c|}{ No. $(\%)$ of Rs-challenged fish positive $\left[\log _{10}\left(R s\right.\right.$ cells $\left.g^{-1}\right)$, mean $\left.\pm \mathrm{SD}\right]$} & \multirow{2}{*}{$\begin{array}{l}\text { Total no. of sham } \\
\text { control fish } \\
\text { positive }(\%)\end{array}$} \\
\hline & Week 3 & Week 12 & Week 21 & Total & \\
\hline \multicolumn{6}{|l|}{ Gill nPCR } \\
\hline Wisconsin & $27(90)$ & 25 (83) & $23(77)$ & 75 (83) & $1(1)$ \\
\hline Washington & 30 (100) & $29(97)$ & $20(67)$ & 79 (88) & $2(2)$ \\
\hline Combined & $57(95)^{\mathrm{A}}$ & $54(90)^{\mathrm{A}}$ & $43(72)^{\mathrm{B}}$ & $154(86)$ & $3(2)$ \\
\hline \multicolumn{6}{|l|}{ Gill qPCR } \\
\hline \multirow[t]{2}{*}{ Wisconsin } & $23(77)$ & $19(63)^{*}$ & $18(60)$ & $60(67)$ & $0(-)$ \\
\hline & {$[4.78 \pm 0.35]^{*}$} & {$[5.12 \pm 0.98]$} & {$[4.55 \pm 0.60]$} & {$[4.82 \pm 0.70]^{*}$} & \\
\hline \multirow[t]{2}{*}{ Washington } & $29(97)$ & $28(93)^{*}$ & $13(43)$ & $70(78)$ & $1(1)$ \\
\hline & {$[5.08 \pm 0.54]^{*}$} & {$[5.17 \pm 0.78]$} & {$[4.78 \pm 0.54]$} & {$[5.06 \pm 0.62]^{*}$} & \\
\hline Combined & $\begin{array}{c}52(87)^{\mathrm{A}} \\
{[4.95 \pm 0.49]^{\mathrm{A}}}\end{array}$ & $\begin{array}{c}47(78)^{\mathrm{A}} \\
{[5.15 \pm 0.82]^{\mathrm{A}}}\end{array}$ & $\begin{array}{c}31(52)^{\mathrm{B}} \\
{[4.65 \pm 0.57]^{\mathrm{B}}}\end{array}$ & $\begin{array}{c}130(72) \\
{[4.95 \pm 0.67]}\end{array}$ & $1(1)$ \\
\hline \multicolumn{6}{|l|}{ Fin nPCR } \\
\hline Wisconsin & $22(73)$ & $23(77)^{*}$ & $23(77)$ & $68(76)$ & $1(1)$ \\
\hline Washington & $22(73)$ & $30(100)^{*}$ & $16(53)$ & $68(76)$ & $2(2)$ \\
\hline Combined & $44(73)^{\mathrm{B}}$ & $53(88)^{\mathrm{A}}$ & $39(65)^{\mathrm{B}}$ & $136(76)$ & $3(2)$ \\
\hline \multicolumn{6}{|l|}{ Fin $q P C R$} \\
\hline Wisconsin & $\begin{array}{c}15(50) \\
{[4.88 \pm 1.00]}\end{array}$ & $\begin{array}{c}15(50) \\
{[5.09 \pm 0.92]}\end{array}$ & $\begin{array}{c}18(60)^{*} \\
{[4.51 \pm 0.76]}\end{array}$ & $\begin{array}{c}48(53) \\
{[4.81 \pm 0.91]}\end{array}$ & $0(-)$ \\
\hline Washington & $\begin{array}{c}12(40) \\
{[4.54 \pm 0.73]}\end{array}$ & $\begin{array}{c}23(77) \\
{[4.74 \pm 0.88]}\end{array}$ & $\begin{array}{c}9(30)^{*} \\
{[4.18 \pm 0.37]}\end{array}$ & $\begin{array}{c}44(49) \\
{[4.57 \pm 0.78]}\end{array}$ & $0(-)$ \\
\hline Combined & $\begin{array}{c}27(45)^{\mathrm{A}} \\
{[4.73 \pm 0.89]^{\mathrm{AB}}}\end{array}$ & $\begin{array}{c}38(63)^{\mathrm{A}} \\
{[4.88 \pm 0.90]^{\mathrm{A}}}\end{array}$ & $\begin{array}{c}27(45)^{\mathrm{A}} \\
{[4.40 \pm 0.67]^{\mathrm{B}}}\end{array}$ & $\begin{array}{c}92(51) \\
{[4.70 \pm 0.85]}\end{array}$ & $0(-)$ \\
\hline \multicolumn{6}{|l|}{ Mucus nPCR } \\
\hline Wisconsin & $27(90)$ & $30(100)$ & $30(100)$ & 87 (97) & $10(11)$ \\
\hline Washington & $30(100)^{\mathrm{A}}$ & $30(100)^{\mathrm{A}}$ & $30(100)^{\mathrm{A}}$ & $90(100)$ & $10(11)$ \\
\hline Combined & $57(95)^{\mathrm{A}}$ & $60(100)^{\mathrm{A}}$ & $60(100)^{\mathrm{A}}$ & $177(98)$ & $20(11)$ \\
\hline \multicolumn{6}{|l|}{ Mucus qPCR } \\
\hline Wisconsin & $\begin{array}{c}23(77) \\
{[4.89 \pm 0.50]}\end{array}$ & $\begin{array}{c}30(100) \\
{[5.72 \pm 0.79]}\end{array}$ & $\begin{array}{c}29(97) \\
{[5.15 \pm 0.64]}\end{array}$ & $\begin{array}{c}82(91) \\
{[5.29 \pm 0.75]}\end{array}$ & $1(1)$ \\
\hline Washington & $\begin{array}{c}27(90) \\
{[4.83 \pm 0.49]}\end{array}$ & $\begin{array}{c}30(100) \\
{[5.90 \pm 1.03]}\end{array}$ & $\begin{array}{c}27(90) \\
{[5.00 \pm 0.69]}\end{array}$ & $\begin{array}{c}84(93) \\
{[5.27 \pm 0.91]}\end{array}$ & $2(2)$ \\
\hline Combined & $\begin{array}{c}50(83)^{\mathrm{B}} \\
{[4.86 \pm 0.49]^{\mathrm{B}}}\end{array}$ & $\begin{array}{c}60(100)^{\mathrm{A}} \\
{[5.81 \pm 0.92]^{\mathrm{A}}}\end{array}$ & $\begin{array}{c}56(93)^{\mathrm{AB}} \\
{[5.08 \pm 0.67]^{\mathrm{B}}}\end{array}$ & $\begin{array}{c}166(92) \\
{[5.28 \pm 0.83]}\end{array}$ & $3(2)$ \\
\hline
\end{tabular}

samples from challenged fish by nPCR $(9 \%)$ and qPCR (3\%) (data not shown); therefore, this tissue type was not included in our analyses. In comparison to $R$. salmoninarum DNA detection rates by nPCR and qPCR in kidney samples, detection rates were significantly higher by nPCR $(p<0.0001)$ and qPCR ( $\mathrm{p} \leq 0.002)$ in gill, fin, and mucus samples. Testing by either nPCR or qPCR detected $R$. salmoninarum DNA at a significantly higher prevalence in mucus samples than in each of the other candidate non-lethal sample types $(p<0.0001)$, and at a significantly higher prevalence in gill samples than in fin samples $(p \leq 0.02)$. For each candidate non-lethal sample type, the $R$. salmoninarum prevalence detected by nPCR was significantly higher than that detected by qPCR $(p<0.05)$. However, false positive results from testing of sham-challenged fish were higher by nPCR testing than by qPCR testing for a given sample type, ranging from $2 \%$ to $11 \%$ of control fish for nPCR and 0 to $2 \%$ of control fish for qPCR (Table 3).

Investigation of patterns of $R$. salmoninarum prevalence among sample time points and between fish stocks showed some similarities between results from 
testing candidate non-lethal samples and kidney samples (Table 3). The $R$. salmoninarum detection rates in all candidate non-lethal sample types except gill were highest at Week 12. For both fish stocks combined, the $R$. salmoninarum prevalence was significantly higher in gill samples by nPCR testing ( $\mathrm{p} \leq$ $0.01)$ and $q P C R$ testing ( $\mathrm{p} \leq 0.002)$ at Weeks 3 and 12 than at Week 21, prevalence was significantly higher in fin samples by nPCR testing at Week 12 than at Weeks 3 and 21 ( $\leq$ 0.04), and prevalence was significantly higher in mucus samples by qPCR testing at Week 12 than at Week $3(p=0.001)$. Similar to a trend observed for kidney samples at Week 12, R. salmoninarum prevalence was significantly higher in the Washington stock than in the Wisconsin stock by gill qPCR testing $(\mathrm{p}=0.01)$ and by fin $\mathrm{nPCR}$ testing $(\mathrm{p}=$ 0.01 ) at this time point. Fin qPCR testing showed significantly higher $R$. salmoninarum prevalence in Wisconsin fish than in Washington fish at Week 21 $(\mathrm{p}=0.04)$.

Quantity estimates obtained by qPCR testing of candidate non-lethal samples ranged from 3.90 to $8.60 \log _{10}\left(R\right.$. salmoninarum cells $\mathrm{g}^{-1}$ ) for gill samples, from 3.68 to $7.50 \log _{10}\left(\right.$ cells $\mathrm{g}^{-1}$ ) for fin samples, and from 3.99 to $9.55 \log _{10}\left(\right.$ cells $\mathrm{g}^{-1}$ ) for mucus samples. Overall, the $R$. salmoninarum levels detected by qPCR were significantly higher in mucus samples than in gill samples $(\mathrm{p}<0.01)$ or fin samples $(\mathrm{p}<$ 0.001 ), and the $R$. salmoninarum levels detected in gill samples were significantly higher than those detected in fin samples ( $p<0.001$ ). In addition, the overall $R$. salmoninarum levels detected by qPCR in mucus samples were significantly higher than the levels detected by qPCR in kidney samples ( $\mathrm{p}<$ 0.001), but levels detected by qPCR in gill and fin samples were not significantly different from kidney sample levels ( $\mathrm{p}>0.05)$.

Comparisons of $R$. salmoninarum qPCR quantity estimates for candidate non-lethal samples among sample time points showed the highest $R$. salmoninarum DNA levels at Week 12 (Table 3). For both fish stocks combined, the $R$. salmoninarum levels in gill samples were significantly higher at Weeks 3 and 12 than at Week 21 ( $p<0.05)$, levels in fin samples were significantly higher at Week 12 than at Week 21 ( p < 0.01 ), and levels in mucus samples were higher at Week 12 than at Week 3 or at Week 21 ( $p<0.001)$. The only sample type showing significant differences in $R$. salmoninarum quantity estimates between fish stocks was gill: $R$. salmoninarum levels in this sample were higher in Washington fish than in Wisconsin fish at Week $3(\mathrm{p}=0.03)$ and for all sample time points combined ( $\mathrm{p}=0.005)$ (Table 3$)$.

\section{Histopathological evaluation of surface-exposed tissues}

Gill was the only surface-exposed tissue that was sampled from all fish for analysis by histopathology and IHC. Eight of the challenged fish (4\%) tested positive for $R$. salmoninarum antigen in gill tissues; 6 of these IHC-positive fish were from the Washington stock. Kidney samples from both of the Wisconsin fish with IHC-positive gill samples and 3 of the Washington fish with IHC-positive gill samples also tested IHC-positive. The gill IHC staining occurred in 3 patterns: (1) staining in the cytoplasm of a few scattered macrophages observed in filaments and lamellae of a single Washington fish at Week 21 (photo not shown), (2) staining in focal inflammatory gill lesions (see Fig. S1A,B in the Supplement at www.int-res.com/articles/suppl/d114p021_supp.pdf) observed in 3 Washington fish at Week 3, and (3) more diffuse staining in vascular spaces, phagocytic cells and exfoliated cells with less pronounced inflammatory changes (see Fig. S1C,D), observed in 4 fish (1 Wisconsin fish and 2 Washington fish at Week 12, and 1 Wisconsin fish at Week 21). The last staining pattern occurred in fish with systemic $R$. salmoninarum infections as determined by IHC staining and positive blood qPCR results (data not presented). For the 3 Washington fish with IHC-positive gill samples and IHC-negative kidney samples, qPCR $R$. salmoninarum quantity estimates for gill samples were higher (5.61 to $5.98 \log _{10}$ [cells $\mathrm{g}^{-1}$ ]) than qPCR quantity estimates for kidney samples (0 to $4.04 \log _{10}$ [cells $\left.\mathrm{g}^{-1}\right]$ ). None of the 10 fin or skin samples from challenged fish that were analyzed by histopathology and IHC tested positive for $R$. salmoninarum antigen.

\section{Diagnostic sensitivity and specificity of candidate non-lethal assays, and concordance with kidney assay results}

One important consideration for evaluation of non-lethal testing as a proxy for kidney sample analysis was whether PCR testing of the candidate non-lethal samples could be used to distinguish $R$. salmoninarum-exposed fish from non-exposed fish. Estimates of diagnostic sensitivity and specificity, and $95 \%$ CI for PCR testing of candidate non-lethal samples were calculated using $R$. salmoninarum immersion-challenged fish and shamchallenged fish as $R$. salmoninarum-positive and $R$. salmoninarum-negative reference animals, res- 
pectively (Table 4). Estimated diagnostic sensitivity (true-positive detection rate) ranged from $51 \%$ for fin $\mathrm{qPCR}$ to $98 \%$ for mucus nPCR; only mucus nPCR and mucus qPCR showed diagnostic sensitivity $>90 \%$. Estimated diagnostic specificity (truenegative detection rate) for $R$. salmoninarum detection in candidate non-lethal samples was $\geq 89 \%$ for all assays.

The LRs of positive (LR+) and negative (LR-) test results and estimates of $95 \% \mathrm{CI}$ were also calculated for PCR detection of $R$. salmoninarum in candidate non-lethal samples (Table 4). The highest LR+ value was calculated for fin $\mathrm{qPCR}$, and indicated that a positive test result was about 185 times more likely to come from an $R$. salmoninarum-exposed fish rather than an unexposed fish. The only assays showing low LR- values $(<0.1)$ were mucus nPCR and mucus qPCR. The high DOR values (Table 4) for all PCR assays ( $\geq 156$ ) indicated much higher odds of a tested sample being correctly classified than misclassified. The highest DOR value (582) was calculated for mucus qPCR.

Concordance analysis of positive and negative results from the $R$. salmoninarum-exposed and unexposed fish was performed to assess agreement of results beyond chance between individual kidney tissue assays and candidate non-lethal sample assays for $R$. salmoninarum detection. The strength of agreement between kidney ELISA, culture, nPCR, and qPCR and non-lethal assay results, expressed by the $\mathrm{k}$-statistic, ranged from fair to almost perfect (see Table S1 in the Supplement at www.int-res.com/ articles/suppl/d114p021_supp.pdf). The highest agreement (almost perfect, $\kappa=0.83$ to 0.90 ) was ob- served between kidney ELISA and gill nPCR, mucus $\mathrm{nPCR}$, and mucus qPCR. Substantial agreement of results ( $\kappa=0.71$ to 0.73 ) was observed between kidney ELISA and gill qPCR and fin nPCR, whereas agreement between kidney ELISA and fin qPCR results was moderate $(\kappa=0.51)$. Moderate agreement ( $\kappa=0.42$ to 0.51 ) was observed between results of kidney nPCR and all the candidate non-lethal assays analyzed, and fair to moderate agreement of results was observed between kidney culture and the nonlethal assays ( $\kappa=0.37$ to 0.49 ), and between kidney qPCR and the non-lethal tests ( $\kappa=0.29$ to 0.46$)$. Only slight to fair agreement was observed between kidney DFAT ( $\kappa=0.09$ to 0.21 ) or kidney IHC ( $\kappa=0.08$ to 0.21 ) and the non-lethal assays (data not shown).

\section{Comparison of $\boldsymbol{R}$. salmoninarum infection intensity estimates from testing of kidney samples and candidate non-lethal samples}

The $\mathrm{nPCR}$ and $\mathrm{qPCR}$ testing of candidate nonlethal samples generally showed increased $R$. salmoninarum detection rates with increasing kidney infection severity, with the highest $R$. salmoninarum prevalence detected for fish in the severe infection stage category (Table 5). All of the assays except fin qPCR detected $R$. salmoninarum DNA in $>90 \%$ of fish in the severe infection stage category, and in $>50 \%$ of fish in the mild infection stage category. Only mucus nPCR and mucus qPCR detected $R$. salmoninarum DNA in $\geq 90 \%$ of fish in all infection stage categories, and in $100 \%$ of fish in the severe infection stage category.

Table 4. Estimated diagnostic sensitivity (true-positive rate) and specificity (true-negative rate), and likelihood ratios (LR) for positive (LR+) and negative (LR-) results of $\mathrm{nPCR}$ and $\mathrm{qPCR}$ for detection of Renibacterium salmoninarum in candidate non-lethal samples from juvenile Chinook salmon Oncorhynchus tshawytscha that had been challenged with the bacterium by immersion and sampled at Weeks 3, 12, and 21 after challenge (180 fish) or exposed to diluent only (180 fish). The R. salmoninarum-exposed fish were considered true positives, and the sham-challenged fish were considered true negatives. TP $=$ true positives, FN $=$ false negatives, $\mathrm{TN}=$ true negatives, $\mathrm{FP}=$ false positives, diagnostic sensitivity $=\mathrm{TP} /(\mathrm{TP}+\mathrm{FN})$, diagnostic specificity $=\mathrm{TN} /(\mathrm{FP}+\mathrm{TN}), \mathrm{LR}+=$ sensitivity/(1 - specificity), LR- = (1 - sensitivity $) /$ specificity, diagnostic odds ratio = LR+ /LR-

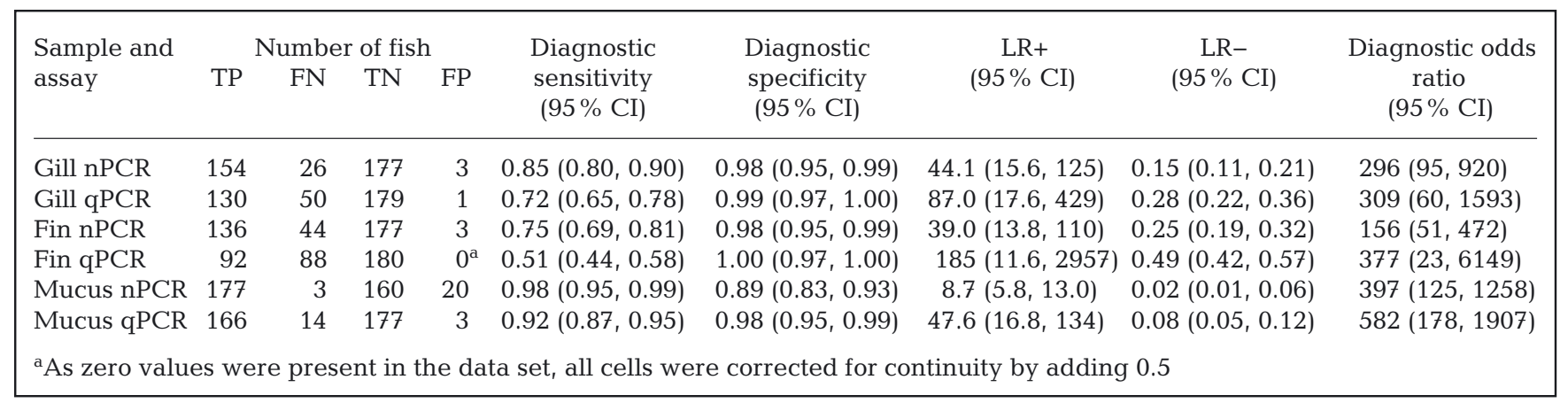


Table 5. Number (and percentage in brackets) of immersion-challenged Chinook salmon Oncorhynchus tshawytscha positive for Renibacterium salmoninarum by nPCR and qPCR testing of candidate non-lethal samples, grouped into 3 infection stage categories based on the results of kidney sample testing by 6 assays (ELISA, culture, nPCR, qPCR, direct fluorescent antibody test [DFAT], and immunohistochemistry [IHC]). The $R$. salmoninarum infection stage in an individual fish was defined by the number of kidney assays that gave positive results for that fish

\begin{tabular}{|c|c|c|c|c|c|c|c|}
\hline \multirow{2}{*}{$\begin{array}{l}\text { Infection stage } \\
\text { (no. of kidney } \\
\text { assays positive) }\end{array}$} & \multirow{2}{*}{$\begin{array}{c}\text { No. of fish } \\
\text { in infection } \\
\text { stage category }\end{array}$} & \multicolumn{6}{|c|}{ No. of fish in category positive by candidate non-lethal assay $(\%)$} \\
\hline & & nPCR & qPCR & nPCR & qPCR & nPCR & qPCR \\
\hline Mild (1-2) & 93 & $75(81)$ & $52(67)$ & $60(65)$ & $34(37)$ & $90(97)$ & $84(90)$ \\
\hline Moderate (3-4) & 61 & $55(90)$ & $44(72)$ & $51(84)$ & $37(61)$ & $61(100)$ & $56(92)$ \\
\hline Severe (5-6) & 26 & 24 (92) & 24 (92) & 25 (96) & 21 (81) & $26(100)$ & $26(100)$ \\
\hline
\end{tabular}

To obtain a more quantitative measure of correlation between kidney $R$. salmoninarum infection levels and qPCR quantity estimates of $R$. salmoninarum in candidate non-lethal samples, we performed correlation analysis using a composite kidney infection intensity score calculated from the results of the quantitative and semi-quantitative assays (Table 6). At each sample point or with all sample time points and fish stocks combined, significant positive correlation was observed between kidney infection intensity scores and both fin and mucus qPCR quantity estimates ( $\mathrm{p} \leq$ 0.02) but not gill qPCR quantity estimates ( $p \geq 0.09$ ). Analysis of data from all Wisconsin fish sampled also showed significant positive correlation between kidney infection intensity scores and both fin and mucus qPCR quantity estimates ( $p \leq 0.005$ ) but not gill qPCR quantity estimates ( $p=0.28$ ). In comparison, for the Washington stock, significant positive correlation was observed between kidney infection intensity scores and mucus qPCR quantity estimates, ( $\mathrm{p}=$ 0.0002 ) but not fin or gill qPCR quantity estimates $(p \geq 0.10)$. For significant correlations $(\mathrm{p} \leq 0.01)$, the $\mathrm{r}_{\mathrm{S}}$ values ranged from 0.31 to 0.65 .

We also examined correlations between values obtained from testing kidney tissues by individual semiquantitative or quantitative assays and $R$. salmoninarum quantity estimates from qPCR testing of candidate non-lethal samples (see Table S2 in the Supplement at www.int-res.com/articles/suppl/d114 p021_supp.pdf). For both fish stocks and all sample
Table 6. Correlation between Renibacterium salmoninarum (Rs) infection intensity scores (calculated by adding values from the quantitative and semiquantitative kidney assays, see Table 2$)$ and quantity estimates $\left(\log _{10}[R s\right.$ cells $\mathrm{g}^{-1}$ ]) obtained from testing of candidate non-lethal samples from the same fish by qPCR. Values were obtained from Chinook salmon Oncorhynchus tshawytscha that had been challenged with $R$. salmoninarum by immersion 3 to $21 \mathrm{wk}$ before sampling and had tested positive for $R s$ in both samples in the comparison. $\mathrm{r}_{\mathrm{S}}=$ Spearman's rank correlation coefficient

\begin{tabular}{|lccc|}
\hline $\begin{array}{l}\text { Sample compared with } \\
\text { kidney Rs intensity score }\end{array}$ & $\begin{array}{c}\text { Number } \\
\text { of fish }\end{array}$ & $\mathrm{r}_{\mathrm{S}}(95 \% \mathrm{CI})$ & $\mathrm{p}$ \\
\hline Week 3 (all fish) & & & \\
Gill qPCR & 52 & $0.10(-0.18,0.37)$ & 0.47 \\
Fin qPCR & 27 & $0.50(0.13,0.74)$ & 0.009 \\
Mucus qPCR & 50 & $0.56(0.33,0.73)$ & $<0.0001$ \\
Week 12 (all fish) & & & \\
Gill qPCR & 47 & $-0.07(-0.36,0.23)$ & 0.65 \\
Fin qPCR & 38 & $0.44(0.13,0.67)$ & 0.006 \\
Mucus qPCR & 60 & $0.57(0.36,0.72)$ & $<0.0001$ \\
Week 21 (all fish) & & & \\
Gill qPCR & 31 & $0.19(-0.19,0.52)$ & 0.31 \\
Fin qPCR & 27 & $0.46(0.08,0.72)$ & 0.02 \\
Mucus qPCR & 56 & $0.33(0.07,0.55)$ & 0.01 \\
All weeks (all fish) & & & \\
Gill qPCR & 130 & $0.15(-0.03,0.32)$ & 0.09 \\
Fin qPCR & 92 & $0.44(0.26,0.60)$ & $<0.0001$ \\
Mucus qPCR & 166 & $0.36(0.21,0.49)$ & $<0.0001$ \\
All weeks (Wisconsin stock) & & & \\
Gill qPCR & 60 & $0.14(-0.12,0.39)$ & 0.28 \\
Fin qPCR & 48 & $0.65(0.44,0.79)$ & $<0.0001$ \\
Mucus qPCR & 82 & $0.31(0.09,0.50)$ & 0.005 \\
All weeks (Washington stock) & & & \\
Gill qPCR & 70 & $0.16(-0.08,0.39)$ & 0.18 \\
Fin qPCR & 44 & $0.25(-0.06,0.52)$ & 0.10 \\
Mucus qPCR & 84 & $0.40(0.19,0.57)$ & 0.0002 \\
\hline
\end{tabular}

time points combined, significant positive correlation was observed between values for each of the kidney assays except IHC and both fin qPCR (p $\leq 0.002)$ and mucus $\mathrm{qPCR}(\mathrm{p} \leq 0.007)$ quantity estimates. The ELISA, DFAT, and IHC values showed significant positive correlation with gill qPCR quantity estimates $(p \leq 0.008)$. Analysis of data for the Wisconsin stock 
fish revealed significant positive correlation between values for each of the kidney assays included in the analysis (ELISA, culture, and qPCR) and fin qPCR quantity estimates ( $p \leq 0.002)$, but only kidney qPCR showed significant positive correlation with mucus qPCR quantity estimates $(p=0.0002)$, and only ELISA showed significant positive correlation with gill qPCR quantity estimates $(p=0.03)$. For the Washington fish, no significant correlation was observed between values for any of the kidney assays and $R$. salmoninarum quantity estimates for any of the candidate non-lethal assays ( $p \geq 0.06$ ). The $r_{S}$ values for significant correlations $(p \leq 0.03)$ ranged from 0.23 to 0.73 .

\section{DISCUSSION}

This research demonstrated that mucus, gill, and fin samples can be taken non-lethally from Chinook salmon as small as $2.8 \mathrm{~g}$, and that Renibacterium salmoninarum DNA can be successfully detected by nPCR and qPCR in these samples taken at intervals up to at least 5 mo after an immersion challenge with the bacterium. For use as a proxy for lethal kidney sample testing to detect and quantify $R$. salmoninarum in juvenile fish, qPCR testing of mucus samples exhibited the best overall diagnostic performance characteristics among the candidate non-lethal assays. Mucus qPCR was the only candidate nonlethal assay showing estimates of both diagnostic sensitivity and specificity greater than $90 \%$, and also yielded the highest DOR value among these assays, suggesting the highest accuracy of positive and negative results for distinguishing between $R$. salmoninarum-exposed and non-exposed fish in the tested population. Additionally, the R. salmoninarum levels detected by mucus qPCR generally corresponded to changes in bacterial load estimated by kidney sample testing, as indicated by significant positive correlations observed between mucus qPCR $R$. salmoninarum quantity estimates and kidney $R$. salmoninarum infection intensity scores at each sample time point from Week 3 to Week 21 after challenge, and in both stocks of Chinook salmon used.

$R$. salmoninarum quantity estimates obtained by qPCR testing of fin tissue also showed significant positive correlations with kidney $R$. salmoninarum infection intensity scores at each sample time point when results for both fish stocks were combined, but correlations between fin qPCR values and kidney infection intensity scores were only significant for 1 of the 2 fish stocks. Although estimated diagnostic specificity of fin qPCR was $100 \%$, the estimated diag- nostic sensitivity for this assay was lower than that for all other mucus, gill, and fin assays. Gill qPCR showed high estimated diagnostic specificity and estimated diagnostic sensitivity between that of mucus qPCR and fin qPCR, but there was no significant correlation between gill qPCR quantity estimates and kidney $R$. salmoninarum infection intensity scores at any sample time point or for either fish stock.

The apparent inhibition of nPCR and qPCR detection of $R$. salmoninarum in blood samples was not surprising because a number of PCR-inhibitory components, including hemoglobin and lactoferrin, have been identified in blood (Abu Al-Soud \& Rådström 2001). Since samples other than blood were determined to be more suitable for non-lethal testing of juvenile fish in the target 3-15 g weight range, we did not attempt modifications to the DNA extraction or PCR protocols for blood samples to control inhibition. However, both conventional reverse-transcription PCR (Rhodes et al. 1998) and qPCR (Bruno et al. 2007) methods that have been reported to show high sensitivity for detection of $R$. salmoninarum nucleic acids in blood samples would be appropriate for nonlethal sampling of adult salmonids.

At least some of the $R$. salmoninarum DNA detected by PCR testing of external samples - gill, fin, and mucus - may have represented bacteria that had been shed into the water by infected fish and became passively associated with the surface mucus or tissues. The bacterial flora detected in or on fish tissues that are exposed to the external environment often reflects the microbial population present in the surrounding water (Cahill 1990, Austin 2006). R. salmoninarum cells were detected at low levels (mean $\leq 1 \log _{10}\left[\right.$ cell ml $\mathrm{ml}^{-1}$ ]) by SPC in the water of all tanks holding $R$. salmoninarum-challenged fish at each sample time point, but quantity estimates from qPCR testing of externally exposed samples were several orders of magnitude higher (mean $>4 \log _{10}\left[\right.$ cells $\left.{ }^{-1}\right]$ ), suggesting that $R$. salmoninarum concentration, proliferation, or both, occurred in the surface mucus or tissues during the post-challenge holding period. Adhesion of bacteria to the surface mucus of fish is an initial step for many microbial infections (Benhamed et al. 2014), but affinity of $R$. salmoninarum for fish mucus has not been investigated. $R$. salmoninarum infections have been reported in the skin, fins, and gills of salmonids (Hoffmann et al. 1984, Ferguson 1989, Bruno et al. 2013), and superficial blisters and shallow ulcers in the integument are commonly described signs of systemic BKD. In addition, an R. salmoninarum skin infection known as 'spawning rash' is observed primarily in sexually maturing salmonids 
(particularly rainbow trout Oncorhynchus mykiss) and manifests as a pustulous dermatitis that may occur in the absence of detectable lesions elsewhere in the body, including the kidney, and resolves after spawning (Ferguson 1989).

The possibility of persistence of $R$. salmoninarum in surface mucus or tissues of asymptomatic fish has received little attention. In our study, $R$. salmoninarum was detected in kidney tissues as well as surface-exposed samples from challenged fish at all time points, but gross clinical signs of BKD were uncommon and BKD lesions were detected by histopathology and IHC in only $10 \%$ of fish examined. However, the moderate to high $R$. salmoninarum antigen levels revealed in $100 \%$ of challenged fish by ELISA testing of kidney tissues did not necessarily confirm the presence of active kidney infections. Antigen produced by $R$. salmoninarum can persist at high levels for more than $110 \mathrm{~d}$ in the absence of live bacteria (Pascho et al. 1997). In addition, ELISA can detect soluble $R$. salmoninarum antigen that circulates into kidney tissues from infections at other sites in the body (Pascho et al. 1987, Elliott \& Pascho 2001). The presence of high levels of $R$. salmoninarum antigen in the absence of clinical signs has been previously reported for ELISA testing of kidney tissues from wild and hatchery stocks of salmonid fishes, particularly trout, char and grayling species that are considered to have reduced susceptibility to clinical BKD but are suspected to serve as reservoirs of infection (Meyers et al. 1993, 2003, Jónsdóttir et al. 1998). Nevertheless, the site(s) where the bacterium might reside as subclinical infections in these fish have not been identified. The relatively high prevalence and $R$. salmoninarum DNA concentrations detected in surface samples, especially mucus, in our study makes them worthy candidates for future investigations of subclinical $R$. salmoninarum infections, particularly for fish populations in which active kidney infections are difficult to demonstrate.

It is also possible that $R$. salmoninarum in water can be retained and perhaps concentrated in the surface mucus of some fish without causing tissue infections, especially in fish culture facilities with relatively crowded conditions. In such cases, detection of $R$. salmoninarum DNA would be an indication of exposure but not necessarily infection, particularly if DNA quantity estimates are near detection threshold limits.

Surface mucus has been determined to be an effective material for non-lethal detection by culture of the gram-negative pathogen Aeromonas salmonicida in salmonid fishes that are asymptomatic carriers of the bacterium as well as in systemically infected fish (Cipriano et al. 1992, 1994). Mucus sampling has been used for early diagnosis and monitoring of the development of clinical $A$. salmonicida infections because the bacterium has been shown to progressively displace the normal surface bacterial flora and can be cultured from surface mucus of asymptomatic fish several weeks before kidney infections can be detected (Cipriano et al. 1994). As the results of our research indicated that $R$. salmoninarum DNA quantity estimates in surface mucus samples reflected changes in kidney infection intensity in the challenged fish, the potential prognostic capabilities of mucus sampling for $R$. salmoninarum detection warrants further investigation.

Previous field tests of salmonid gill tissue as a potential non-lethal sample for $R$. salmoninarum detection by PCR have produced variable results. One study used nPCR and qPCR to test 240 hatcheryorigin steelhead trout (anadromous Oncorhynchus mykiss) out-migrating from the Snake River in the Pacific Northwest USA, and showed no significant difference $(\mathrm{p}>0.05)$ in $R$. salmoninarum detection rates between kidney and gill tissue samples, but significantly higher detection rates $(\mathrm{p} \leq 0.0015)$ by $\mathrm{nPCR}$ than qPCR in each tissue (McMichael et al. 2006). A subsequent 3 yr study also used nPCR and qPCR to detect $R$. salmoninarum in gill samples taken nonlethally from yearling hatchery-origin and wildorigin steelhead trout and Chinook salmon outmigrants in the Snake River, with 1447 to 1800 total fish and approximately equal numbers of fish of each origin sampled per year (Ryan et al. 2007, Marsh et al. 2008, 2010, Badil et al. 2011). The prevalence of $R$. salmoninarum DNA detected in the gill samples showed year-to-year variation and prevalence was usually higher by qPCR (21 to $64 \%$ ) than by nPCR (16 to $36 \%$ ). For fish that tested positive during a given year, $R$. salmoninarum DNA quantity estimates in gill samples by qPCR were $<5 \log _{10}$ (bacteria) $\mathrm{g}^{-1}$ in $\geq 95 \%$ of fish. In contrast to the field results with juvenile steelhead trout and Chinook salmon, testing of 40 spawning female Atlantic salmon Salmo salar at a farm in Iceland detected $R$. salmoninarum DNA in gill samples of only 2 fish by nPCR, whereas 12 kidney samples $(30 \%)$ from the same fish tested positive (Arnason et al. 2013).

Several factors may have contributed to the lack of correlation between gill sample $R$. salmoninarum DNA quantity estimates and kidney infection intensity scores in challenged fish in our study. The IHC findings of focal gill infections, in addition to the rel- 
atively high gill qPCR DNA quantity estimates that showed no significant correlation with kidney $R$. salmoninarum infection intensity scores, suggested that localized gill infections developed independent of kidney infections in some fish. Nevertheless, it could not be determined with certainty whether these localized infections were initiated by entry of bacteria through the gill epithelium or represented bacteria that were picked up in other sites by phagocytes that subsequently circulated to the gills (CamposPerez et al. 2000). In comparison to our results with Chinook salmon, research conducted with rainbow trout demonstrated little or no uptake of live $R$. salmoninarum cells into gill tissue following exposure of isolated perfused heads, whole fish via gill flushing, or excised gill pieces, suggesting that gills of this species are unlikely to serve as sites for attachment and uptake of the pathogen (McIntosh et al. 2000), although the gills of rainbow trout may be a point of entry for other bacterial pathogens such as Yersinia ruckeri (McIntosh et al. 2000) and Aeromonas salmonicida (Hodgkinson et al. 1987). Besides possible fish species differences in the occurrence of $R$. salmoninarum gill infections, there may also be differences among fish stocks within a species, as our results suggested. The qPCR quantity estimates and IHC results from gill tissue analyses indicated higher overall bacterial loads associated with $R$. salmoninarum gill infections in the Washington Chinook salmon stock than in the Wisconsin stock. In contrast, data from the quantitative and semi-quantitative assays did not show fish stock differences in $R$. salmoninarum kidney infection intensity. As the organ with the greatest surface area exposed to the environment (Ferguson 1989) and a significant component of the mucosal immune system (Gomez et al. 2013), the gill may play a significant role in the immune response to $R$. salmoninarum, as has been suggested by the results of limited research on cellular and immune gene expression responses of gill tissue following experimental exposure of fish or gill explants to the bacterium (Flaño et al. 1996, CamposPerez et al. 2000).

The lower $R$. salmoninarum prevalence detected by PCR in pelvic fin samples in comparison to gill or mucus samples may have been partly a reflection of the relatively smaller externally exposed surface area of the fin samples, resulting in reduced exposure to the waterborne bacteria. Nevertheless, among fish with fin samples that tested positive for $R$. salmoninarum by qPCR, correlation analysis showed a strong positive association between $R$. salmoninarum infection intensity in fin and kidney tissue for 1 of the fish stocks (Wisconsin) and for both fish stocks combined. Hyperemia and hemorrhaging at the bases of fins are common clinical signs of BKD (Smith 1964, Kimura 1978, Warren 1991), and careful examination of the affected tissues may reveal septic thrombosis associated with $R$. salmoninarum infections (Ferguson 1989). The involvement in BKD of major blood vessels and organs such as the heart (Bruno 1986), and the sensitive detection of $R$. salmoninarum nucleic acids in blood by some PCRs (Rhodes et al. 1998, Bruno et al. 2007) suggest that hematogenous distribution of bacteria is common during $R$. salmoninarum infections (Speare et al. 1993, Speare 1997). The significant positive correlation between kidney and fin $R$. salmoninarum levels observed in our study may have been indicative of developing bacteremia in these fish.

The detection of $R$. salmoninarum DNA in the blood of some challenged fish by qPCR, coupled with IHC detection of $R$. salmoninarum antigens in vascular spaces in the gills of the same fish, showed the presence of bacteremia in these fish. The bacterium has previously been demonstrated by histopathology in vascular spaces of the gills of other salmonid species (Ferguson 1989, Bruno et al. 2013), and within cells exfoliating from the lamellar surface (Ferguson 1989, McIntosh et al. 2000), as was also observed in our study. Phagocytosis of pathogens and foreign material by epithelial cells of the gills and skin, and subsequent sloughing of the cells, may be a mechanism to help protect against pathogen invasion and potentially harmful substances (Åsbakk \& Dalmo 1998), but this process may also be a means whereby pathogens are disseminated into the surrounding water for potential infection of other fish.

To evaluate the performance of candidate nonlethal assays as proxies for kidney tissue testing, we used composite reference standards based on results from multiple kidney assays in addition to comparisons between individual kidney assays and the non-lethal assays, because we believed that the composite metrics would convey a more complete representation of kidney infection status in a fish for several reasons. First, previous research has not identified a single gold standard assay demonstrating error-free diagnostic performance characteristics for detection and quantification of $R$. salmoninarum in kidney tissue (Elliott et al. 2013). When a gold standard assay does not exist, a composite reference standard combining several imperfect assays can provide a better perspective on infection status than a single imperfect assay (Naaktgeboren et al. 2013). Several investigators have reported that use of 
results from more than 1 assay - including culture, ELISA, and nPCR (Faisal \& Eissa 2009), ELISA and qPCR (Nance et al. 2010), FAT and histopathology/ immunohistochemistry (White et al. 1996), ELISA and FAT (Elliott et al. 1997), and ELISA, culture, FAT, qPCR, and histopathology (Bruno et al. 2007) - can improve evaluations of the presence and stage of $R$. salmoninarum infections in fish. Second, the kidney assays we used detect different $R$. salmoninarum analytes, and the occurrence and abundance of these analytes may vary at different stages of infection (Meyers et al. 1993, Hamel \& Anderson 2002, Cvitanich 2004, Faisal \& Eissa 2009, Nance et al. 2010, Kent et al. 2013). Use of a composite kidney infection intensity score in our research provided an assessment of infection status in each fish based on the presence and levels of several different analytes, and allowed analysis of correlation between kidney infection intensity results and $R$. salmoninarum DNA quantity estimates for each fish with gill, fin, or mucus samples testing positive by qPCR. Third, because non-uniform distribution of $R$. salmoninarum in infected fish can affect detection by individual assays (Meyers et al. 1993, Bruno et al. 2007), use of results from multiple assays can improve the accuracy of $R$. salmoninarum evaluations. Finally, in accord with previous research (Elliott et al. 1997, 2013, Powell et al. 2005, Bruno et al. 2007, Nance et al. 2010, Arnason et al. 2013), our results from kidney sample testing with multiple assays generally showed greater agreement with increasing $R$. salmoninarum infection severity (as evaluated by values from the quantitative and semi-quantitative assays) and enabled the establishment of infection severity categories based on the number of kidney assays showing positive results for a given fish.

The use of a composite kidney infection intensity score for analysis of correlations with qPCR quantity estimates from candidate non-lethal samples in this study provided more consistent results than comparisons with individual kidney assays. Although the $r_{S}$ values obtained for significant positive correlations $(\mathrm{p}<0.05)$ between kidney infection intensity scores and fin or mucus $\mathrm{qPCR}$ values were moderate $\left(\mathrm{r}_{\mathrm{S}} \leq\right.$ 0.65), significant positive correlations with similarly moderate $r_{S}$ values $\left(r_{S} \leq 0.61\right)$ have also been reported for comparisons of ELISA, qPCR, and culture results from testing a single tissue (kidney) from naturally or experimentally $R$. salmoninarum-infected juvenile Chinook salmon (Nance et al. 2010, Elliott et al. 2013), and likely reflect differences in distribution and relative concentrations of analytes detected by the various assays at different infection stages, as previously discussed. In addition, analyte concentrations detected by some assays may not correspond directly to bacterial loads, particularly when bacterial loads are very low or very high (Hamel \& Anderson 2002, Elliott et al. 2013).

The choice between nPCR and qPCR for analysis of non-lethal samples for $R$. salmoninarum detection may depend on cost considerations, the need for quantitative results, and whether avoidance of false positive or false negative results is more important (Elliott et al. 2013). Our results indicated higher sensitivity of nPCR for $R$. salmoninarum detection in the candidate non-lethal samples, and start-up and operational costs are lower for nPCR than for qPCR (Purcell et al. 2011). Conversely, advantages of qPCR over nPCR, in addition to quantitative abilities, include higher throughput, reproducibility and robustness, and reduction of contamination by elimination of a second round of amplification and post-PCR manipulation of products (Purcell et al. 2011). Although we could not entirely dismiss the possibility that PCR positives among candidate non-lethal samples tested from sham-challenged fish represented detection of $R$. salmoninarum present at very low levels in some control fish, evidence suggested that spurious $\mathrm{nPCR}$ bands or DNA contamination were likely the cause of these positive results. Pre-challenge testing of kidney tissues from a sub-sample of the experimental fish yielded no positive results, and testing of kidney samples from each sham-challenged fish by 6 different assays produced a total of only 5 positive results. In addition, there was no consistent pattern of positive results obtained by testing different candidate non-lethal samples from the same control fish, and the $C_{\mathrm{T}}$ values from the 4 qPCRpositive control fish were all near the negativepositive threshold, suggestive of contamination. We did not attempt sequencing PCR products to confirm that $\mathrm{nPCR}$ bands represented target DNA, but sequencing might not distinguish between tissue infections and laboratory contamination because of low genetic diversity among $R$. salmoninarum strains (Brynildsrud et al. 2014).

In summary, PCR testing of mucus samples provided the best option for non-lethal $R$. salmoninarum detection in juvenile Chinook salmon in our laboratory study. Mucus samples can also be easily obtained in a non-destructive manner under field conditions. Additionally, surface mucus and any underlying epidermal cells removed during sampling are quickly regenerated (Elliott 2000), which could allow repeated sampling of the same fish over time. Detection of $R$. salmoninarum DNA by PCR at higher 
prevalence and higher overall concentrations in mucus than in kidney samples suggested that mucus might be useful for monitoring subclinical infections and changes in infection prevalence and intensity in response to factors such as alterations in fish culture practices or environmental conditions. Further research on the relation between PCR detection of $R$. salmoninarum in mucus samples and infection progression should be conducted with salmonids of different species and stocks in naturally infected populations. The most effective non-lethal sample type for a pathogen will depend on the infection strategy of that pathogen (Cornwell et al. 2013), and there is still much to learn about the mechanisms of entry and establishment of $R$. salmoninarum in the fish host.

Acknowledgements. This work was supported by the Great Lakes Fishery Trust (Project 2006.835) and by the US Geological Survey. We acknowledge Taylor Alton, Sacha Mosterd, James Woodson, Samantha Badil, Rachel Thompson, and Christine Nguyen for assistance with laboratory studies and data collection, analysis, and interpretation, and James Winton for a critical review of the manuscript. We thank Susan Marcquenski (Wisconsin Department of Natural Resources [DNR]) for advice on various aspects of this research and for assistance with obtaining Chinook salmon eggs for this study. We also thank the Wisconsin DNR Northwest Region Hatchery and Operations crew, Kettle Moraine Springs Hatchery personnel, Wild Rose Hatchery personnel, the Wisconsin DNR Central Office Fish Health Expeditionary Force, and personnel at the Washington State Department of Fish and Wildlife Soos Creek Hatchery for assistance in obtaining the eggs and adult fish samples for Renibacterium salmoninarum testing. The mention of trade, firm, or corporation names in this publication is for the information and convenience of the reader and does not constitute an official endorsement or approval by the US Geological Survey or the Department of the Interior of any product or service to the exclusion of others that may be suitable.

\section{LITERATURE CITED}

Abu Al-Soud W, Rådström P (2001) Purification and characterization of PCR-inhibitory components in blood cells. J Clin Microbiol 39:485-493

AFS-FHS (American Fisheries Society-Fish Health Section) (2014) FHS blue book: Suggested procedures for the detection and identification of certain finfish and shellfish pathogens, 2014 edn. http://afs-fhs.org/bluebook/ bluebook-index.php

> Akobeng AK (2007) Understanding diagnostic tests 2: likelihood ratios, pre- and post-test probabilities and their use in clinical practice. Acta Paediatr 96:487-491

> Alcorn S, Murray AL, Pascho RJ, Varney J (2005) A cohabitation challenge to compare the efficacies of vaccines for bacterial kidney disease (BKD) in chinook salmon Oncorhynchus tshawytscha. Dis Aquat Org 63:151-160

Altinok I, Grizzle JM, Liu Z (2001) Detection of Yersinia ruckeri in rainbow trout blood by use of the polymerase chain reaction. Dis Aquat Org 44:29-34
Arnason IÖ, Sigurdardottir S, Kristmundsson A, Svansson V, Gudmundsdottir S (2013) Evaluation of a semi-nested PCR for detection of Renibacterium salmoninarum in samples from kidney, gill and ovarian fluid of Atlantic salmon broodfish. Icel Agric Sci 26:49-57

Åsbakk K, Dalmo RA (1998) Atlantic salmon (Salmo salar L.) epidermal Malpighian cells - motile cells clearing away latex beads in vitro. J Mar Biotechnol 6:30-34

> Austin B (2006) The bacterial microflora of fish, revised. Sci World J 6:931-945

Austin B, Embley TM, Goodfellow M (1983) Selective isolation of Renibacterium salmoninarum. FEMS Microbiol Lett 17:111-114

Avendaño-Herrera R, Nuñez S, Magariños B, Toranzo AE (2004) A non-destructive method for detection of Tenacibaculum maritinum in farmed fish using nested PCR amplification. Bull Eur Assoc Fish Pathol 24:280-285

> Badil S, Elliott DG, Kurobe T, Hedrick RP, Clemens K, Blair M, Purcell MK (2011) Comparative evaluation of molecular diagnostic tests for Nucleospora salmonis and prevalence in migrating juvenile salmonids from the Snake River, USA. J Aquat Anim Health 23:19-29

> Balfry SK, Albright LJ, Evelyn TPT (1996) Horizontal transfer of Renibacterium salmoninarum among farmed salmonids via the fecal-oral route. Dis Aquat Org 25:63-69

Bell GR, Higgs DA, Traxler GS (1984) The effect of dietary ascorbate, zinc, and manganese on the development of experimentally induced bacterial kidney disease in sockeye salmon (Oncorhynchus nerka). Aquaculture 36:293-311

- Benediktsdóttir E, Helgason S, Gudmundsdóttir S (1991) Incubation time for the cultivation of Renibacterium salmoninarum from Atlantic salmon, Salmo salar L., broodfish. J Fish Dis 14:97-102

- Benhamed S, Guardiola FA, Mars M, Esteban MÁ (2014) Pathogen bacteria adhesion to skin mucus of fishes. Vet Microbiol 171:1-12

Bowers RM, Lapatra SE, Dhar AK (2008) Detection and quantification of infectious pancreatic necrosis virus by real-time reverse transcriptase-polymerase chain reaction using lethal and non-lethal tissue sampling. J Virol Methods 147:226-234

Bruno DW (1986) Histopathology of bacterial kidney disease in laboratory infected rainbow trout, Salmo gairdneri Richardson, and Atlantic salmon, Salmo salar L., with reference to naturally infected fish. J Fish Dis 9:523-537

> Bruno DW, Munro ALS (1986) Observations on Renibacterium salmoninarum and the salmonid egg. Dis Aquat Org 1:83-87

Bruno D, Collet B, Turnbull A, Kilburn R and others (2007) Evaluation and development of diagnostic methods for Renibacterium salmoninarum causing bacterial kidney disease (BKD) in the UK. Aquaculture 269:114-122

Bruno DW, Noguera PA, Poppe TT (2013) A colour atlas of salmonid diseases, 2nd edn. Springer, London

> Brynildsrud O, Feil EJ, Bohlin J, Castillo-Ramirez S and others (2014) Microevolution of Renibacterium salmoninarum: evidence for intercontinental dissemination associated with fish movements. ISME J 8:746-756

Cahill MM (1990) Bacterial flora of fishes: a review. Microb Ecol 19:21-41

Campos-Perez JJ, Ward M, Grabowski PS, Ellis AE, Secombes CJ (2000) The gills are an important site of iNOS expression in rainbow trout Oncorhynchus mykiss after challenge with the gram-positive pathogen Renibacterium salmoninarum. Immunology 99:153-161 
Caraguel CGB, Stryhn H, Gagné N, Dohoo IR, Hammell KL (2011) Selection of a cutoff value for real-time polymerase chain reaction results to fit a diagnostic purpose: analytical and epidemiological approaches. J Vet Diagn Invest 23:2-15

Carson FL, Martin JH, Lynn JA (1973) Formalin fixation for electron microscopy: a re-evaluation. Am J Clin Pathol 59:365-373

Chase DM, Pascho RJ (1998) Development of a nested polymerase chain reaction for amplification of a sequence of the p57 gene of Renibacterium salmoninarum that provides a highly sensitive method for detection of the bacterium in salmonid kidney. Dis Aquat Org 34:223-229

Chase DM, Elliott DG, Pascho RJ (2006) Detection and quantification of Renibacterium salmoninarum DNA in salmonid tissues by real-time quantitative polymerase chain reaction analysis. J Vet Diagn Invest 18:375-380

> Cipriano RC, Ford LA, Teska JD, Hale LE (1992) Detection of Aeromonas salmonicida in the mucus of salmonid fishes. J Aquat Anim Health 4:114-118

Cipriano RC, Ford LA, Schachte JH, Petrie C (1994) Evaluation of mucus as a valid site to isolate Aeromonas salmonicida among asymptomatic populations of lake trout (Salvelinus namaycush). Biomed Lett 49:229-233

Coady AM, Murray AL, Elliott DG, Rhodes LD (2006) Both msa genes in Renibacterium salmoninarum are needed for full virulence in bacterial kidney disease. Appl Environ Microbiol 72:2672-2678

Cornwell ER, Bellmund CA, Groocock GH, Wong PT, Hambury KL, Getchell RG, Bowser PR (2013) Fin and gill biopsies are effective nonlethal samples for detection of viral hemorrhagic septicemia virus genotype IVb. J Vet Diagn Invest 25:203-209

Cvitanich JD (2004) Renibacterium salmoninarum bar forms: characterization, occurrence, and evidence of a host response to a $R$. salmoninarum infection. J Fish Dis 27:193-211

> Dhar AK, Bowers RM, Licon KS, LaPatra SE (2008) Detection and quantification of infectious hematopoietic necrosis virus in rainbow trout (Oncorhynchus mykiss) by SYBR Green real-time reverse transcriptase-polymerase chain reaction. J Virol Methods 147:157-166

> Douglas-Helders M, Carson J, Howard T, Nowak B (2001) Development and validation of a new dot blot test for the detection of Paramoeba pemaquidensis (Page) in fish. J Fish Dis 24:273-280

Elliott DG (2000) Integumentary system: microscopic functional anatomy. In: Ostrander GK (ed) The laboratory fish. Academic Press, London, p 271-306

- Elliott DG, McKibben CL (1997) Comparison of two fluorescent antibody techniques (FATs) for detection and quantification of Renibacterium salmoninarum in coelomic fluid of spawning chinook salmon Oncorhynchus tshawytscha. Dis Aquat Org 30:37-43

Elliott DG, Pascho RJ (2001) Evidence that coded-wiretagging procedures can enhance transmission of Renibacterium salmoninarum in chinook salmon. J Aquat Anim Health 13:181-193

Elliott DG, Pascho RJ, Jackson LM, Matthews GM, Harmon JR (1997) Renibacterium salmoninarum in spring-summer chinook salmon smolts at dams on the Columbia and Snake Rivers. J Aquat Anim Health 9:114-126

Elliott DG, Applegate LJ, Murray AL, Purcell MK, McKibben CL (2013) Bench-top validation testing of selected immunological and molecular Renibacterium salmonina- rum diagnostic assays by comparison with quantitative bacteriological culture. J Fish Dis 36:779-809

Evelyn TPT (1977) An improved growth medium for the kidney disease bacterium and some notes on using the medium. Bull Off Int Epizoot 87:511-513

Evelyn TPT (1993) Bacterial kidney disease-BKD. In: Inglis V, Roberts RJ, Bromage NR (eds) Bacterial diseases of fish. Halsted Press, New York, NY, p 177-195

Evelyn TPT, Ketcheson JE, Prosperi-Porta L (1981) The clinical significance of immunofluorescence-based diagnoses of the bacterial kidney disease carrier. Fish Pathol 15: 293-300

Evelyn TPT, Ketcheson JE, Prosperi-Porta L (1984) Further evidence for the presence of Renibacterium salmoninarum in salmonid eggs and for the failure of povidoneiodine to reduce the intra-ovum infection rate in waterhardened eggs. J Fish Dis 7:173-182

> Evelyn TPT, Prosperi-Porta L, Ketcheson JE (1986) Persistence of the kidney-disease bacterium, Renibacterium salmoninarum, in coho salmon, Oncorhynchus kisutch (Walbaum), eggs treated during and after water-hardening with povidone-iodine. J Fish Dis 9:461-464

> Evenden AJ, Grayson TH, Gilpin ML, Munn CB (1993) Renibacterium salmoninarum and bacterial kidney diseasethe unfinished jigsaw. Annu Rev Fish Dis 3:87-104

Faisal M, Eissa AE (2009) Diagnostic testing patterns of Renibacterium salmoninarum in spawning salmonid stocks in Michigan. J Wildl Dis 45:447-456

Ferguson HW (1989) Systemic pathology of fish. Iowa State University Press, Ames, IA

Ferguson HW (ed) (2006) Systemic pathology of fish, 2nd edn. Scotian Press, London

Fisheries and Oceans Canada (1984, revised 2004) Fish health protection regulations: manual of compliance. Fisheries and Marine Service Miscellaneous Special Publications 31 (revised), Ottawa

> Flaño E, López-Fierro P, Razquin BE, Villena A (1996) In vitro differentiation of eosinophilic granular cells in Renibacterium salmoninarum-infected gill cultures from rainbow trout. Fish Shellfish Immunol 6:173-184

Fryer JL, Lannan CN (1993) The history and current status of Renibacterium salmoninarum, the causative agent of bacterial kidney disease in Pacific salmon. Fish Res 17: 15-33

> Fryer JL, Sanders JE (1981) Bacterial kidney disease of salmonid fish. Annu Rev Microbiol 35:273-298

Giray C, Opitz HM, MacLean S, Bouchard D (2005) Comparison of lethal versus non-lethal sample sources for the detection of infectious salmon anemia virus (ISAV). Dis Aquat Org 66:181-185

Gomez D, Sunyer JO, Salinas I (2013) The mucosal immune system of fish: the evolution of tolerating commensals while fighting pathogens. Fish Shellfish Immunol 35: 1729-1739

> Gudmundsdóttir S, Helgason S, Benediktsdóttir E (1991) Comparison of three different growth media for primary isolation of Renibacterium salmoninarum from Atlantic salmon, Salmo salar L., broodfish. J Fish Dis 14:89-96

Hamel OS, Anderson JJ (2002) Relationship between antigen concentration and bacterial load in Pacific salmon with bacterial kidney disease. Dis Aquat Org 51:85-92

- Hayakawa Y, Harada T, Hatai K, Kubota SS, Bunya T, Hoshiai G (1989) Histopathology of BKD (bacterial kidney disease) occurred in sea-cultured coho salmon (Oncorhynchus kisutch). Fish Pathol 24:17-21 
Hendricks JD, Leek SL (1975) Kidney disease postorbital lesions in chinook salmon (Oncorhynchus tshawytscha). Trans Am Fish Soc 104:805-807

Hodgkinson JL, Bucke D, Austin B (1987) Uptake of the fish pathogen, Aeromonas salmonicida, by rainbow trout (Salmo gairdneri). FEMS Microbiol Lett 40:207-210

Hoffmann R, Popp W, van de Graaff S (1984) Atypical BKD predominantly causing ocular and skin lesions. Bull Eur Assoc Fish Pathol 4:7-9

> Holey MF, Elliott RF, Marcquenski SV, Hnath JG, Smith KD (1998) Chinook salmon epizootics in Lake Michigan: possible contributing factors and management implications. J Aquat Anim Health 10:202-210

> Jansson E, Hongslo T, Höglund J, Ljungberg O (1996) Comparative evaluation of bacterial culture and two ELISA techniques for the detection of Renibacterium salmoninarum antigens in salmonid kidney tissues. Dis Aquat Org 27:197-206

Jones DL, Brailsford MA, Drocourt JL (1999) Solid-phase, laser-scanning cytometry: a new two-hour method for the enumeration of microorganisms in pharmaceutical water. Pharmacop Forum 25:7626-7645

Jónsdóttir H, Malmquist HJ, Snorrason SS, Gudbergsson G, Gudmundsdóttir S (1998) Epidemiology of Renibacterium salmoninarum in wild Arctic charr and brown trout in Iceland. J Fish Biol 53:322-339

> Kent ML, Benda S, St. Hilaire S, Schreck CB (2013) Sensitivity and specificity of histology for diagnoses of four common pathogens and detection of nontarget pathogens in adult Chinook salmon (Oncorhynchus tshawytscha) in fresh water. J Vet Diagn Invest 25:341-351

Kimura T (1978) Bacterial kidney disease of salmonids. Fish Pathol 13:43-52

LaPatra SE, Rohovec JS, Fryer JL (1989) Detection of infectious hematopoietic necrosis virus in fish mucus. Fish Pathol 24:197-202

Lemarchand K, Parthuisot N, Catala P, Lebaron P (2001) Comparative assessment of epifluorescence microscopy, flow cytometry and solid-phase cytometry used in the enumeration of specific bacteria in water. Aquat Microb Ecol 25:301-309

Lisle JT, Hamilton MA, Willse AR, McFeters GA (2004) Comparison of fluorescence microscopy and solid-phase cytometry methods for counting bacteria in water. Appl Environ Microbiol 70:5343-5348

> López-Vázquez C, Dopazo CP, Olveira JG, Barja JL, Bandín I (2006) Development of a rapid, sensitive and non-lethal diagnostic assay for the detection of viral haemorrhagic septicaemia virus. J Virol Methods 133:167-174

Lovely JE, Cabo C, Griffiths SG, Lynch WH (1994) Detection of Renibacterium salmoninarum infection in asymptomatic Atlantic salmon. J Aquat Anim Health 6:126-132

Marsh DM, Muir WD, Elliott D, Murray T, Applegate L, McKibben C, Mosterd S (2008) Alternative barging strategies to improve survival of transported juvenile salmonids, 2007. Annual report of research prepared for the US Army Corps of Engineers, Walla Walla, WA

Marsh DM, Muir WD, Sandford BP, Elliott D and others (2010) Alternative barging strategies to improve survival of transported juvenile salmonids, 2008. Annual report of research prepared for the US Army Corps of Engineers, Walla Walla, WA

McIntosh D, Austin B, Flaño E, Villena A, Martínez-Pereda JA, Tarazona JV (2000) Lack of uptake of Renibacterium salmoninarum by gill epithelia of rainbow trout. J Fish
Biol 56:1053-1061

McMichael GA, Vucelick JA, Ryan B, Gilbreath L, McComas RL, Smith S, Carper M, Elliott D, Murray T, Applegate L, McKibben C (2006) Alternative barging strategies to improve survival of transported juvenile salmonids, 2005. Annual report of research prepared for the US Army Corps of Engineers, Walla Walla, WA

- Metzger DC, Elliott DG, Wargo A, Park LK, Purcell MK (2010) Pathological and immunological responses associated with differential survival of Chinook salmon following Renibacterium salmoninarum challenge. Dis Aquat Org 90:31-41

> Meyers TR, Short S, Farrington C, Lipson K, Geiger HJ, Gates R (1993) Comparison of the enzyme-linked immunosorbent assay (ELISA) and the fluorescent antibody test (FAT) for measuring the prevalences and levels of Renibacterium salmoninarum in wild and hatchery stocks of salmonid fishes in Alaska, USA. Dis Aquat Org 16:181-189

> Meyers TR, Korn D, Glass K, Burton T, Short S, Lipson K, Starkey N (2003) Retrospective analysis of antigen prevalences of Renibacterium salmoninarum (Rs) detected by enzyme-linked immunosorbent assay in Alaskan Pacific salmon and trout from 1988 to 2000 and management of Rs in hatchery Chinook and coho salmon. J Aquat Anim Health 15:101-110

Mignon-Godefroy K, Guillet JG, Butor C (1997) Solid phase cytometry for detection of rare events. Cytometry 27: 336-344

Mitchum DL, Sherman LE (1981) Transmission of bacterial kidney disease from wild to stocked hatchery trout. Can J Fish Aquat Sci 38:547-551

> Munson AD, Elliott DG, Johnson K (2010) Management of bacterial kidney disease in Chinook salmon hatcheries based on broodstock testing by enzyme-linked immunosorbent assay: a multiyear study. N Am J Fish Manage 30:940-955

> Murray CB, Evelyn TPT, Beacham TD, Barner LW, Ketcheson JE, Prosperi-Porta L (1992) Experimental induction of bacterial kidney disease in chinook salmon by immersion and cohabitation challenges. Dis Aquat Org 12:91-96

Naaktgeboren CA, Bertens LCM, van Smeden M, de Groot JAH, Moons KGM, Reitsma JB (2013) Value of composite reference standards in diagnostic research. BMJ 347 : f5605.

Nance SL, Riederer M, Zubkowski T, Trudel M, Rhodes LD (2010) Interpreting dual ELISA and qPCR data for bacterial kidney disease of salmonids. Dis Aquat Org 91: 113-119

Noga EJ, Levine JF, Townsend K, Bullis RA, Carlson CP, Corbett WT (1988) Kidney biopsy: a non-lethal method for diagnosing Yersinia ruckeri infection (enteric redmouth disease) in rainbow trout (Salmo gairdneri). Am J Vet Res 49:363-365

OIE (Office International des Épizooties) (2003) Manual of diagnostic tests for aquatic animals. Office International des Épizooties, Paris

> Olsen AB, Hopp P, Binde M, Grønstøl H (1992) Practical aspects of bacterial culture for the diagnosis of bacterial kidney disease. Dis Aquat Org 14:207-212

> Pascho RJ, Elliott DG, Mallett RW, Mulcahy D (1987) Comparison of five techniques for the detection of Renibacterium salmoninarum in adult coho salmon. Trans Am Fish Soc 116:882-890

Pascho RJ, Elliott DG, Streufert JM (1991) Brood stock seg- 
regation of spring chinook salmon Oncorhynchus tshawytscha by use of the enzyme-linked immunosorbent assay (ELISA) and the fluorescent antibody technique (FAT) affects the prevalence and levels of Renibacterium salmoninarum infection in progeny. Dis Aquat Org 12: 25-40

Pascho RJ, Goodrich TD, McKibben CL (1997) Evaluation by enzyme-linked immunosorbent assay (ELISA) of Renibacterium salmoninarum bacterins affected by persistence of bacterial antigens. J Aquat Anim Health 9:99-107

Pascho RJ, Chase D, McKibben CL (1998) Comparison of the membrane-filtration fluorescent antibody test, the enzyme-linked immunosorbent assay, and the polymerase chain reaction to detect Renibacterium salmoninarum in salmonid ovarian fluid. J Vet Diagn Invest 10: 60-66

Pascho RJ, Elliott DG, Chase DM (2002) Comparison of traditional and molecular methods for detection of Renibacterium salmoninarum. In: Cunningham CO (ed) Molecular diagnosis of salmonid diseases. Kluwer Academic Publishers, Dordrecht, p 157-209

> Powell M, Overturf K, Hogge C, Johnson K (2005) Detection of Renibacterium salmoninarum in chinook salmon, Oncorhynchus tshawytscha (Walbaum), using quantitative PCR. J Fish Dis 28:615-622

Purcell MK, Murray AL, Elz A, Park LK and others (2008) Decreased mortality of Lake Michigan Chinook salmon after bacterial kidney disease challenge: evidence for pathogen-driven selection? J Aquat Anim Health 20: 225-235

Purcell MK, Getchell RG, McClure CA, Garver KA (2011) Quantitative polymerase chain reaction (PCR) for detection of aquatic animal pathogens in a diagnostic laboratory setting. J Aquat Anim Health 23:148-161

Rhodes LD, Nilsson WB, Strom MS (1998) Sensitive detection of Renibacterium salmoninarum in whole fry, blood, and other tissues of Pacific salmon by reverse transcription-polymerase chain reaction. Mol Mar Biol Biotechnol 7:270-279

Ryan BA, Carper M, Marsh DM, Elliott D and others (2007) Alternative barging strategies to improve survival of transported juvenile salmonids, 2006. Annual report of research prepared for the US Army Corps of Engineers, Walla Walla, WA

Sakai M, Koyama G, Atsuta S, Kobayashi M (1987) Detection

Editorial responsibility: David Bruno,

Aberdeen, UK of Renibacterium salmoninarum by a modified peroxidase-antiperoxidase (PAP) procedure. Fish Pathol 22:1-5 Schrock RM, Beeman JW, Rondorf DW, Haner PV (1994) A microassay for gill sodium, potassium-activated ATPase in juvenile Pacific salmonids. Trans Am Fish Soc 123: 223-229

Skirpstunas RT, Hergert JM, Baldwin TJ (2006) Detection of early stages of Myxobolus cerebralis in fin clips from rainbow trout (Oncorhynchus mykiss). J Vet Diagn Invest 18:274-277

Smith IW (1964) The occurrence and pathology of Dee disease. Freshw Salmon Fish Res 34:1-12

Smith RD (2006) Veterinary clinical epidemiology. Taylor \& Francis, Boca Raton, FL

Speare DJ (1997) Differences in patterns of meningoencephalitis due to bacterial kidney disease in farmed Atlantic and chinook salmon. Res Vet Sci 62:79-80

Speare DJ, Ostland VE, Ferguson HW (1993) Pathology associated with meningoencephalitis during bacterial kidney disease of salmonids. Res Vet Sci 54:25-31

Starliper CE, Teska JD (1995) Relevance of Renibacterium salmoninarum in an asymptomatic carrier population of brook trout, Salvelinus fontinalis (Mitchill). J Fish Dis 18: 383-387

Thrusfield M (2007) Veterinary epidemiology, 3rd edn. Blackwell Science, Oxford

Vanhee LME, D'Haese E, Cools I, Nelis HJ, Coenye T (2010) Detection and quantification of bacteria and fungi using solid-phase cytometry. In: Magni MV (ed) Detection of bacteria, viruses, parasites and fungi: bioterrorism prevention. Springer, Dordrecht, p 25-41

Warren JW (1991) Diseases of hatchery fish. US Fish and Wildlife Service, Portland, OR

White MR, Albregts SR, Wu CC, Breidert B (1996) The use of kidney biopsy of broodstock steelhead trout (Oncorhynchus mykiss) to determine the status of bacterial kidney disease infection. J Vet Diagn Invest 8:519-522

Wolf K, Dunbar CE (1959) Methods of infecting trout with kidney disease and some effects of temperature on experimental infections. Special Scientific Report, Fisheries No. 286, United States Department of the Interior, Fish and Wildlife Service, Washington, DC

Wood JW, Wallis J (1955) Kidney disease in adult chinook salmon and its transmission by feeding to young chinook salmon. Fish Comm Oregon Res Briefs 6:32-40

Submitted: October 7, 2014; Accepted: January 6, 2015

Proofs received from author(s): March 21, 2015 